\title{
Differential Distribution of Three Members of a Gene Family Encoding Low Voltage-Activated (T-Type) Calcium Channels
}

\author{
Edmund M. Talley, ${ }^{1}$ Leanne L. Cribbs, ${ }^{2}$ Jung-Ha Lee, ${ }^{2}$ Asif Daud, ${ }^{2}$ Edward Perez-Reyes, ${ }^{2}$ and \\ Douglas A. Bayliss ${ }^{1}$ \\ ${ }^{1}$ Department of Pharmacology, University of Virginia, Charlottesville, Virginia 22908, and 2Department of Physiology, \\ Loyola University Medical Center, Maywood, Illinois 60153
}

Low voltage-activated (T-type) calcium currents are observed in many central and peripheral neurons and display distinct physiological and functional properties. Using in situ hybridization, we have localized central and peripheral nervous system expression of three transcripts $(\alpha 1 \mathrm{G}, \alpha 1 \mathrm{H}$, and $\alpha 1 \mathrm{l})$ of the T-type calcium channel family $\left(\mathrm{Ca}_{V} \mathrm{~T}\right)$. Each mRNA demonstrated a unique distribution, and expression of the three genes was largely complementary. We found high levels of expression of these transcripts in regions associated with prominent T-type currents, including inferior olivary and thalamic relay neurons (which expressed $\alpha 1 \mathrm{G}$ ), sensory ganglia, pituitary, and dentate gyrus granule neurons $(\alpha 1 \mathrm{H})$, and thalamic reticular neurons $(\alpha 1 \mathrm{l}$ and $\alpha 1 \mathrm{H})$. Other regions of high expression included the Purkinje cell layer of the cerebellum, the bed nucleus of the stria terminalis, the claustrum $(\alpha 1 \mathrm{G})$, the olfactory tubercles $(\alpha 1 \mathrm{H}$ and $\alpha 1 \mathrm{I})$, and the subthalamic nucleus $(\alpha 1 \mathrm{I}$ and $\alpha 1 \mathrm{G})$. Some neurons expressed high levels of all three genes, including hippocampal pyramidal neurons and olfactory granule cells. Many brain regions showed a predominance of labeling for $\alpha 1 \mathrm{G}$, including the amygdala, cerebral cortex, rostral hypothalamus, brainstem, and spinal cord. Exceptions included the basal ganglia, which showed more prominent labeling for $\alpha 1 \mathrm{H}$ and $\alpha 1 \mathrm{l}$, and the olfactory bulb, the hippocampus, and the caudal hypothalamus, which showed more even levels of all three transcripts. Our results are consistent with the hypothesis that differential gene expression underlies pharmacological and physiological heterogeneity observed in neuronal T-type calcium currents, and they provide a molecular basis for the study of T-type channels in particular neurons.

Key words: in situ hybridization; calcium channel; CNS; anticonvulsant; rat; T-type calcium channels
Voltage-dependent calcium channels play a dual role in the CNS; they couple electrical activity to calcium influx, thereby triggering myriad intracellular biochemical events, and they contribute to membrane properties that determine the precise nature of excitability in different cell types. Low voltage-activated (LVA) calcium channels have a hand in both of these roles that is readily distinguishable from their high voltage-activated (HVA) counterparts, in part because they activate at potentials near the resting membrane potential. First, in addition to participating in spikeinduced calcium entry (McCobb and Beam, 1991; Scroggs and Fox, 1992b; Umemiya and Berger, 1994), they allow calcium influx at potentials below threshold. This influx can occur when cells are at rest (Magee et al., 1996) or in response to subthreshold synaptic inputs (Miyakawa et al., 1992; Markram and Sakmann, 1994; Magee et al., 1995). Second, LVA calcium channels can be a crucial component in shaping subthreshold membrane fluctuations and thereby contribute to such behaviors as rebound burst firing (Llinas and Yarom, 1981), rhythmic oscillation (Gutnick and Yarom, 1989; Bal and McCormick, 1993), and resonance (Hutcheon et al., 1994; Puil et al., 1994). Given their proposed

Received Sept. 23, 1998; revised Oct. 28, 1998; accepted Oct. 30, 1998.

This work was supported by National Institutes of Health Grants HL57828 (E.P-R.), NS33583 (D.A.B.), and MH12091 (predoctoral fellowship for E.M.T.). We thank Drs. Madaline B. Harrison, Ruth L. Stornetta, Patrice G. Guyenet, and the Information Technology Services at the University of Virginia for providing imaging equipment and support.

Correspondence should be addressed to Edmund M. Talley, Department of Pharmacology, Box 448, Health Sciences Center, University of Virginia, Charlottesville, VA 22908.

Copyright (C) 1999 Society for Neuroscience $\quad 0270-6474 / 99 / 191895-17 \$ 05.00 / 0$ role in oscillatory behavior, it is perhaps not surprising that LVA calcium channel dysfunction is implicated in epileptiform activity (Tsakiridou et al., 1995) and that these channels are targets for antiepileptic drugs (Coulter et al., 1989b).

Information regarding the structure of calcium channels has been determined primarily from the cloning of genes that encode the subunits forming HVA calcium channels. The central core of these channels consists of an $\alpha 1$ subunit that has four internal repeats, each repeat consisting of six membrane-spanning regions and a pore-forming loop (for review, see Catterall, 1995; PerezReyes and Schneider, 1995). Currently, at least six $\alpha 1$ subunits have been identified that are believed to generate the physiologically and pharmacologically defined HVA calcium channel subtypes (generally designated L, N, P, Q, and R). Although one of these subunits $(\alpha 1 \mathrm{E})$ expresses currents that are transient and whose voltage-dependent properties suggest that it may encode an LVA channel (Soong et al., 1993), the currents produced by this gene do not possess all of the properties that are common for "T-type" LVA calcium channels (e.g., Randall and Tsien, 1997). T-type properties in neurons include low voltage activation, strongly voltage-dependent kinetics, rapid inactivation, slow deactivation, and small single-channel conductance (for review, see Huguenard, 1996).

Recently, a subfamily of genes (designated $\mathrm{Ca}_{\mathrm{V}} \mathrm{T}$ ) has been discovered encoding $\alpha 1$ subunits that are $\sim 30 \%$ homologous to HVA subunit genes in their putative membrane-spanning regions (Cribbs et al., 1998; Perez-Reyes et al., 1998a,b). When expressed heterologously, two of these proteins, $\alpha 1 \mathrm{G}$ and $\alpha 1 \mathrm{H}$, show all the properties hallmark of neuronal T-type calcium channels. A third 
member of this family, designated $\alpha 1 \mathrm{I}$, also encodes a calcium channel that displays a number of T-type properties (Lee et el., 1999).

Given that expression of T-type channels has a unique impact on neuronal properties, it is of great interest to know which neuronal populations express these subunits. Furthermore, T-type channels are pharmacologically and physiologically heterogeneous (Akaike et al., 1991; Huguenard, 1996; Tarasenko et al., 1997). This heterogeneity may reflect different functions of these channels in neurons, and may stem at least in part from differential expression of each of these three genes. Therefore, using in situ hybridization histochemistry, we have localized the regional and cellular distribution of gene expression for the three known members of the $\mathrm{Ca}_{\mathrm{V}} \mathrm{T}$ family in the rat central and peripheral nervous systems. We find that each gene has a unique expression pattern and that the location of these three channel types is to a large extent complementary.

\section{MATERIALS AND METHODS}

Tissue preparation. Male Sprague Dawley rats (250-350 gm; Hilltop) were anesthetized with ketamine-xylazine and decapitated. Brains, spinal cords, and ganglia were removed and frozen on dry ice. Sections (10 $\mu \mathrm{m}$ ) were thaw-mounted onto charged slides (Superfrost Plus; Fisher Scientific, Houston, TX) and stored at $-80^{\circ} \mathrm{C}$ for later use. In preliminary experiments, sagittal and horizontal sections were used from six animals. For detailed comparative analysis, coronal sections from three animals were taken from the entire brain $(\sim 200-500 \mu \mathrm{m}$ apart). In addition, representative sections from three or four animals were taken from nodose, superior cervical, and dorsal root ganglia, as well as from cervical, thoracic, and lumbar spinal cord. Slides were pretreated for hybridization as described previously (Talley et al., 1997). Sections were fixed in $4 \%$ paraformaldehyde ( $5 \mathrm{~min}$ ) and rinsed extensively with PBS, $\mathrm{pH}$ 7.4. They were treated with glycine $(0.2 \%$ in PBS; 5 min) and acetic anhydride $(0.25 \%$ in $0.1 \mathrm{M}$ triethanolamine, $0.9 \%$ saline, $\mathrm{pH} 8 ; 10 \mathrm{~min})$ and subsequently dehydrated in a graded series of ethanols and chloroform. Hybridization was performed overnight at $37^{\circ} \mathrm{C}$ in a buffer of $50 \%$ formamide, $4 \times \mathrm{SSC}(1 \times \mathrm{SSC}: 150 \mathrm{~mm} \mathrm{NaCl}$ and $15 \mathrm{~mm}$ sodium citrate, $\mathrm{pH} 7), 1 \times$ Denhardt's solution $(0.02 \%$ each of Ficoll, polyvinylpyrrolidone, and bovine serum albumin), 10\% dextran sulfate, $100 \mathrm{~mm}$ DTT, $250 \mu \mathrm{g} / \mathrm{ml}$ yeast tRNA, and $0.5 \mathrm{mg} / \mathrm{ml}$ salmon testes DNA. After hybridization, slides were washed through four changes of $1 \times \mathrm{SSC}$ at $55^{\circ} \mathrm{C}$ $(15 \mathrm{~min}$ each) and once for an hour in $1 \times \mathrm{SSC}$ at room temperature.

Oligonucleotide probes. Sequence analysis of $\alpha 1 \mathrm{G}, \alpha 1 \mathrm{H}$, and $\alpha 1 \mathrm{I}$ has revealed a high degree of homology in the putative transmembrane regions of these three genes (Perez-Reyes et al., 1998b). In contrast, there is particularly low conservation in the sequences that connect each of the four repeating domains. Therefore, antisense oligonucleotide probes (33 bases in length) were designed to hybridize to the cytoplasmic I-II "linker" region of the rat homolog of each gene (L. L. Cribbs, J.-H. Lee, and E. Perez-Reyes, unpublished data). Sequences were chosen that had minimal homology both to other calcium channel genes and to other sequences present in GenBank. Probes were labeled using terminal deoxyribonucleotidyl transferase (Life Technologies, Gaithersburg, MD); unincorporated nucleotides were removed using Sephadex G-50 spin columns (Pharmacia, Piscataway, NJ).

Multiple oligonucleotides were used to probe each gene (three oligonucleotides for $\alpha 1 \mathrm{G}$, three for $\alpha 1 \mathrm{H}$, and two for $\alpha 1 \mathrm{I})$. Subsequent to preliminary experiments characterizing the probes, the oligonucleotides corresponding to each gene were hybridized in a cocktail. We found that using the probes in combination resulted in an enhanced signal but had no effect on relative distribution of signal intensities in different brain regions (see below). The concentration of each oligonucleotide was $\sim 30 \times 10^{6} \mathrm{cpm} / \mathrm{ml}(\sim 2 \mathrm{nM})$. The sequences of the probes were as follows: $\alpha 1 \mathrm{G}$ : $5^{\prime}$-CCAGCCCGCACGCCTATAGCCCTAGAGACCTGG-3', 5'-TCCGATGGGCATCTGGGAGGGGGTGCCTGGCAA$3^{\prime}$, and $5^{\prime}$-TGTCGCCGCCGGCTGTGGGGATCCCGGAGGTCA-3'; $\alpha 1 \mathrm{H}: 5^{\prime}$-ATGCCGTACATCCTGGGTAAACTCATAGACTCC-3', 5' AGCCCCTTGGGTCGTGAGCTGGTGCCACCTTTG-3', and 5'-ATCCCTCCTGGTTGTGAGGCCTTCCGCAGTGGT-3'; $\alpha 1$ I: 5'-AGCCACCAGAACCTGAGCCTTCCTGGCCTGAGT-3' and 5'-TCGCGCCACACATCCCCACACAGTCGGGCTGCC-3'.
Control experiments. We performed a number of preliminary control experiments. First, we hybridized each oligonucleotide separately to sagittal and horizontal sections. Cognate oligonucleotides generated an identical tissue distribution, indicating that these independent probes recognized the same gene product and ruling out the possibility of spurious cross-reactivity. Higher wash temperatures $\left(60\right.$ and $65^{\circ} \mathrm{C}$ in $1 \times$ SSC) resulted in diminished hybridization, but for each oligonucleotide the distribution of labeling was unchanged, indicating that the same binding site was labeled in different brain areas. For each set of probes, specific binding was eliminated by prior digestion with RNase A (50 $\mu \mathrm{g} / \mathrm{ml}$; Boehringer Mannheim, Indianapolis, IN). Nonspecific binding was assessed in competition experiments (examples of which are shown in Fig. 3), with $\sim 500$-fold excess unlabeled oligonucleotide $(1 \mu \mathrm{M})$ included in the hybridization mixture. In these experiments, nonspecific binding to tissue was barely distinguishable from the overall background, demonstrating that specific binding was saturable and that nonspecific binding was minimal.

Data analysis and presentation. Slides were exposed to film (Hyperfilm $\beta$-MAX; Amersham, Arlington Heights, IL) for 1 week to generate autoradiograms (Fig. 1), which were analyzed with the aid of image analysis software (MCID; Imaging Research) to determine the relative intensity of labeling in different brain regions. For resolution of cellular labeling, slides also were dipped in liquid autoradiographic emulsion (NTB2; Eastman Kodak, Rochester, NY), exposed for 5-9 weeks, and examined by dark-field and bright-field microscopy. Images of silver grains from these slides (see Figs. 2-7) were captured using a Pixera video camera mounted on a Leitz Diaplan microscope. In addition, high-power bright-field micrographs (such as those shown in Figs. 4, 6, 7) were made of labeled cells from different brain regions for side-by-side comparison of the relative numbers of silver grains overlaying various cell types.

By combining densitometry of film autoradiograms with information on the specific cellular localization of hybridization, we determined the comparative distribution of each of the three transcripts. The results of this analysis are presented in Table 1 as a system of pluses, with five pluses $(+++++)$ representing the highest levels of expression. It is important to understand that because a number of factors other than transcript levels (particularly the hybridization efficiency of individual probes) can affect signal intensity, this scoring system reflects relative amounts of individual transcripts in different brain regions, rather than comparisons among the three different $\mathrm{Ca}_{\mathrm{V}} \mathrm{T}$ transcripts. However, the fact that the various probes to each gene (when hybridized individually) generated similar signal intensities suggests that the influence of factors such as differences in hybridization efficiency were minor. Therefore, relative levels of the three different mRNA species may be compared, so long as such comparison is viewed with caution. In this regard, it is also important to note that only two probes were used to detect $\alpha 1 \mathrm{I}$ (as opposed to three each for $\alpha 1 \mathrm{G}$ and $\alpha 1 \mathrm{H}$ ). As stated above, we found that combining oligonucleotides in a cocktail had no effect on relative distribution but resulted in enhanced signal intensity. Thus, because one fewer probe was used for $\alpha 1 \mathrm{I}$, transcript levels for this gene may have been somewhat under-represented relative to those of the other two genes.

\section{RESULTS \\ Overview}

We performed in situ hybridization to determine the regional distribution of $\mathrm{Ca}_{\mathrm{V}} \mathrm{T}(\alpha 1 \mathrm{G}, \alpha 1 \mathrm{H}$, and $\alpha 1 \mathrm{I})$ gene expression in the central and peripheral nervous systems. Figure 1 shows representative film autoradiograms of transverse sections that were taken through the entire brain. Figures 2-7 show representative darkfield and bright-field images of silver grains from emulsion-dipped slides. The results of combined analysis from film autoradiograms and emulsion-dipped slides are summarized in Table 1.

The distribution of the three transcripts was to a great extent complementary, and the expression pattern of each gene was unique. Only a few regions, including the granule cell layer of the olfactory bulb (Figs. 1 $A, 2$ ), fields CA1 and CA3 of the hippocampus (Figs. $1 G-K, 3$ ), and the tenia tecta (TT; Fig. $1 B$ ), displayed expression of all three transcripts in abundance. Cells with the 


\section{$\alpha 1 G$}
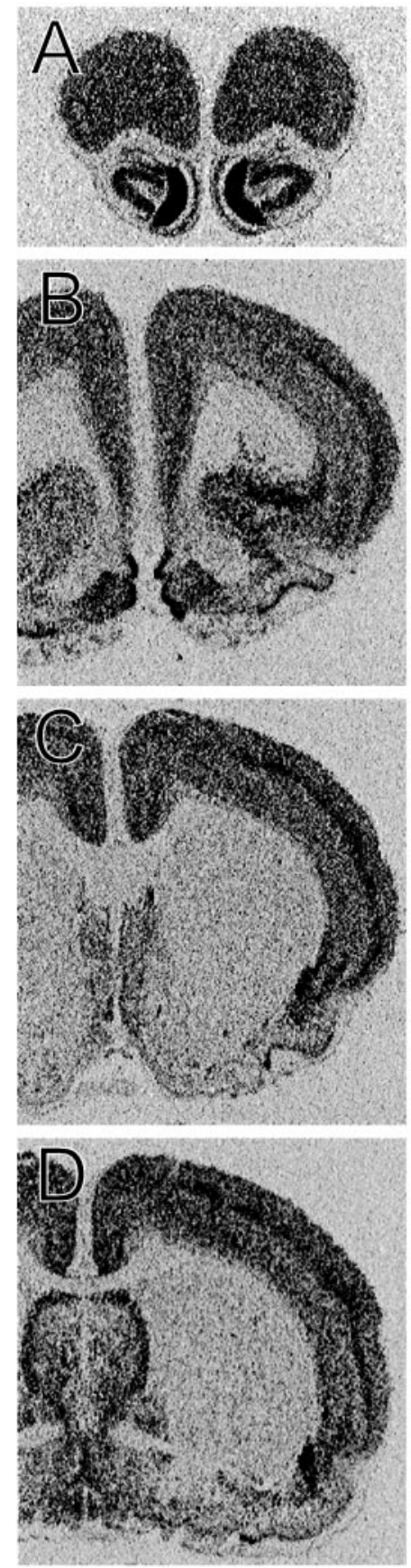

$\alpha 1 \mathrm{H}$
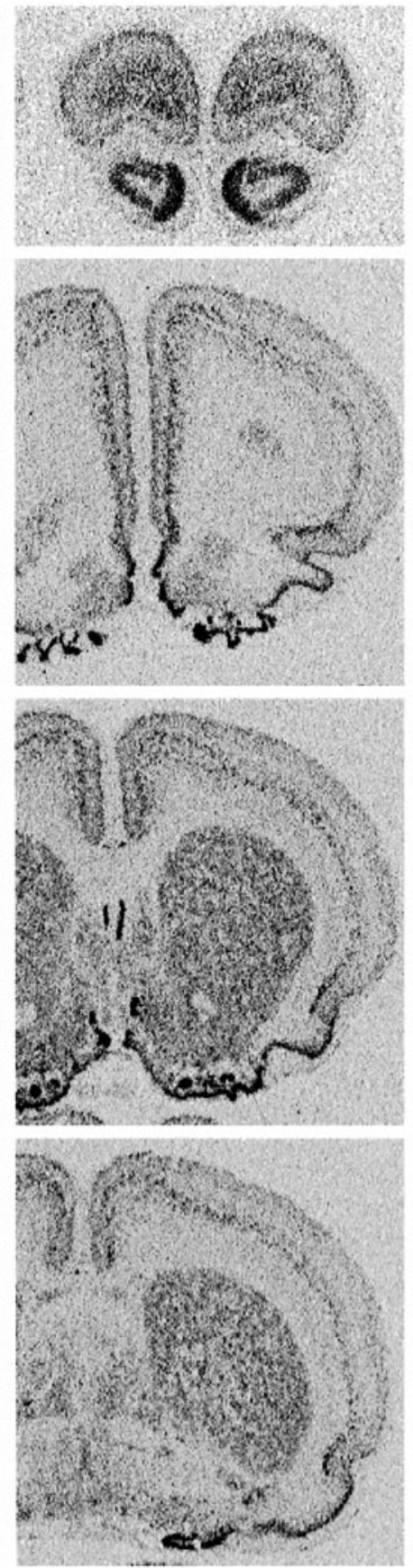

$\alpha 1 \mathrm{I}$
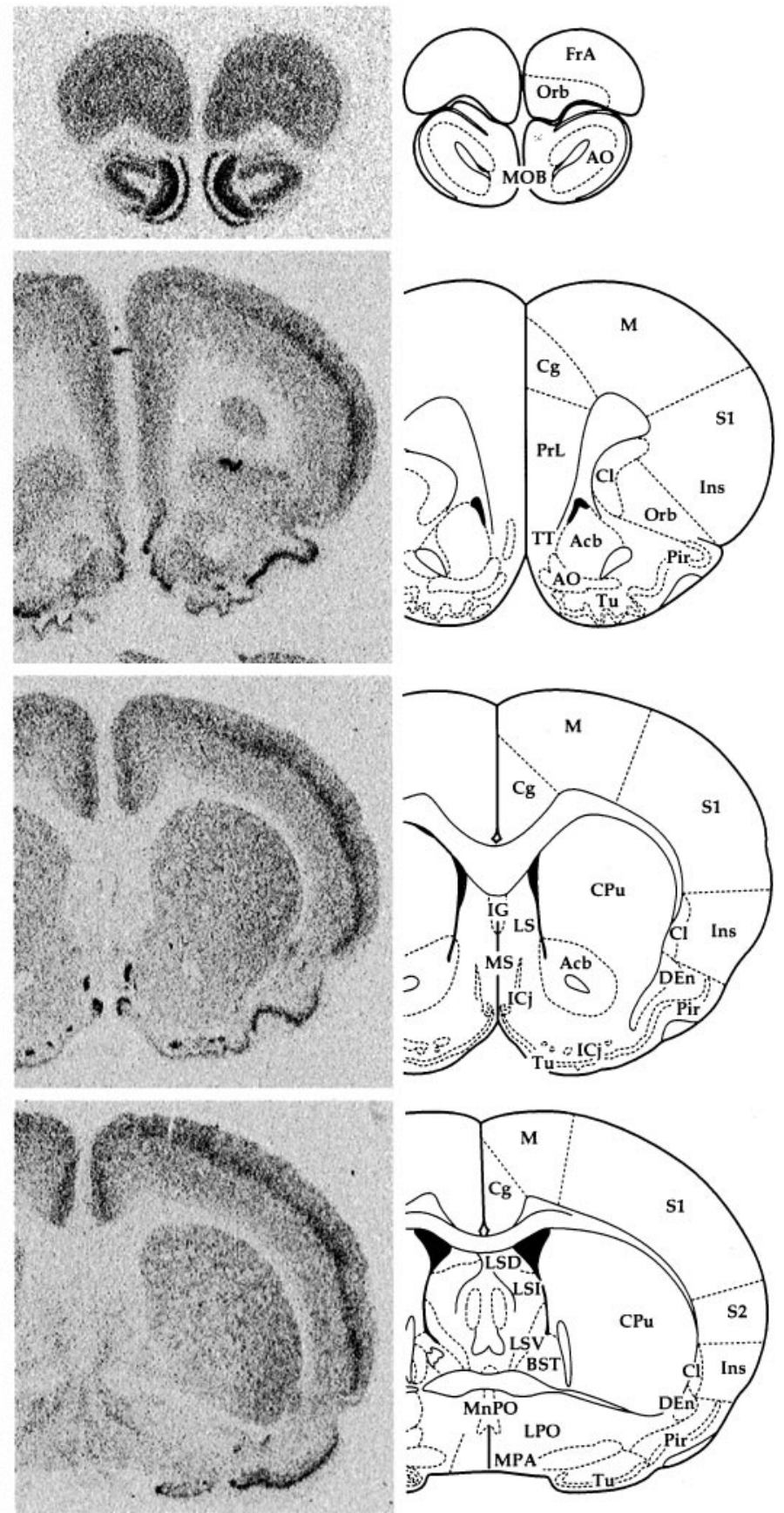

Figure 1. CNS distribution of $\mathrm{Ca}_{\mathrm{V}} \mathrm{T}$ gene expression. Sections were hybridized with oligonucleotides specific for $\alpha 1 \mathrm{G}$ (left panels), $\alpha 1 \mathrm{H}$ (middle panels), and $\alpha 1 \mathrm{I}$ (right panels) and exposed to autoradiographic film. Line drawings on the far right are adapted from Paxinos and Watson (1997; reproduced with permission) and indicate the relevant labeled areas. For abbreviations, refer to Table 2. Figure 1 continues.

highest $\alpha 1 \mathrm{G}$ mRNA levels included cerebellar Purkinje cells (Fig. 6 ), thalamic relay neurons (Fig. 5), inferior olivary cells (InO; Fig. 6 ), and neurons of the bed nucleus of the stria terminalis (BST; Fig. $1 E)$. Labeling for $\alpha 1 \mathrm{H}$ was highest in the olfactory tubercle (Tu; Figs. $1 C, D, 2$ ), granule cells of the dentate gyrus (Figs. $1 G-K, 3$ ), and in sensory ganglia (Fig. 7). Labeling for $\alpha 1 \mathrm{I}$ was highest in the olfactory bulb (Figs. 1 $A, 2$ ), the cell islands of Calleja (ICj; Figs. $1 C, 2$ ), and fields CA1 and CA3 of the hippocampus (Figs. $1 G-K, 3$ ).

\section{Olfactory system}

All three probes gave prominent labeling in the olfactory bulb (MOB; Figs. $1 A, 2$ ). As noted above, the granule cell layer of this structure was one of a limited number of brain regions with high expression of all three channel subtypes. In contrast, the mitral cell layer was not noticeably labeled, and where mitral cells were identified by Nissl stain, silver grains were not detected above background (data not shown). Small neurons in the glomerular 


\section{$\alpha 1 G$}
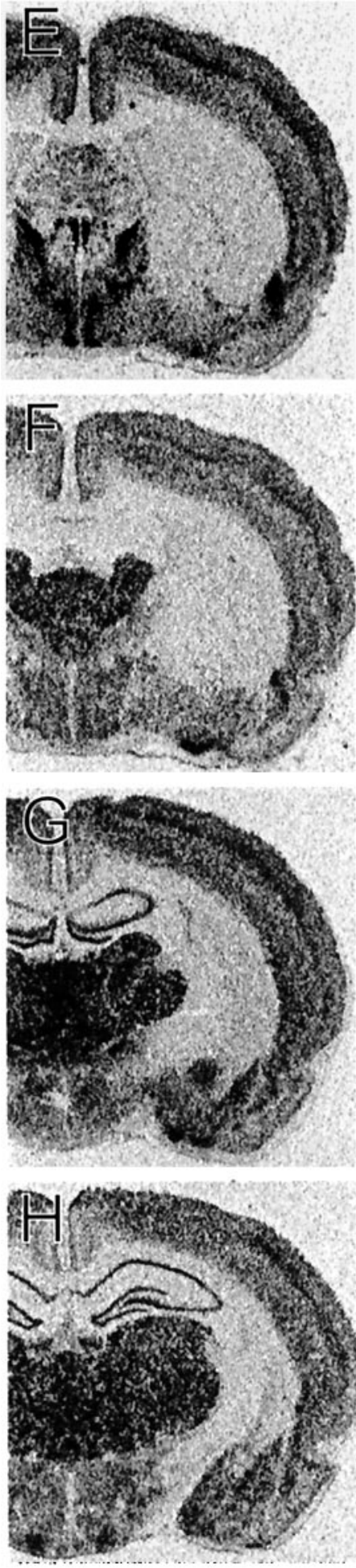

$\alpha 1 \mathrm{H}$
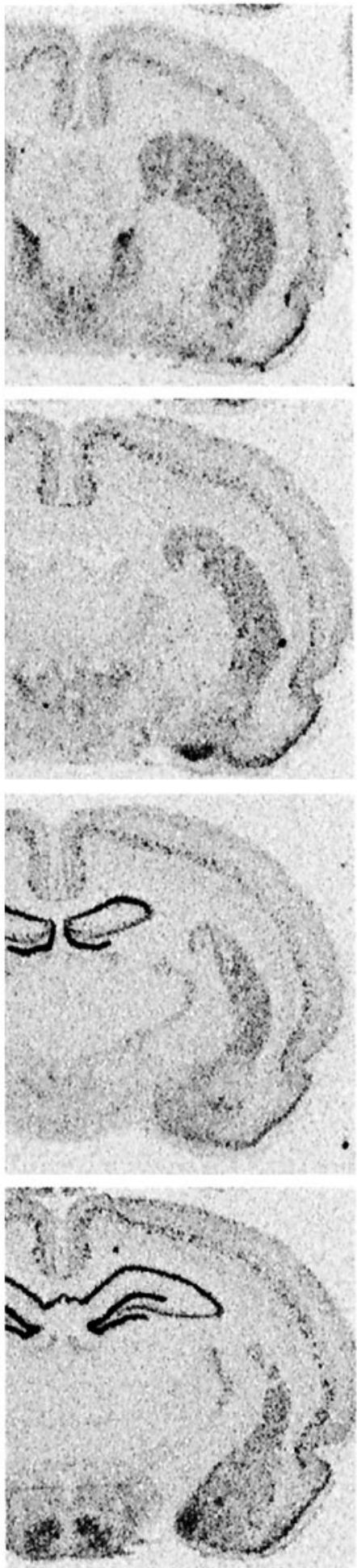

$\alpha 1 \mathrm{I}$
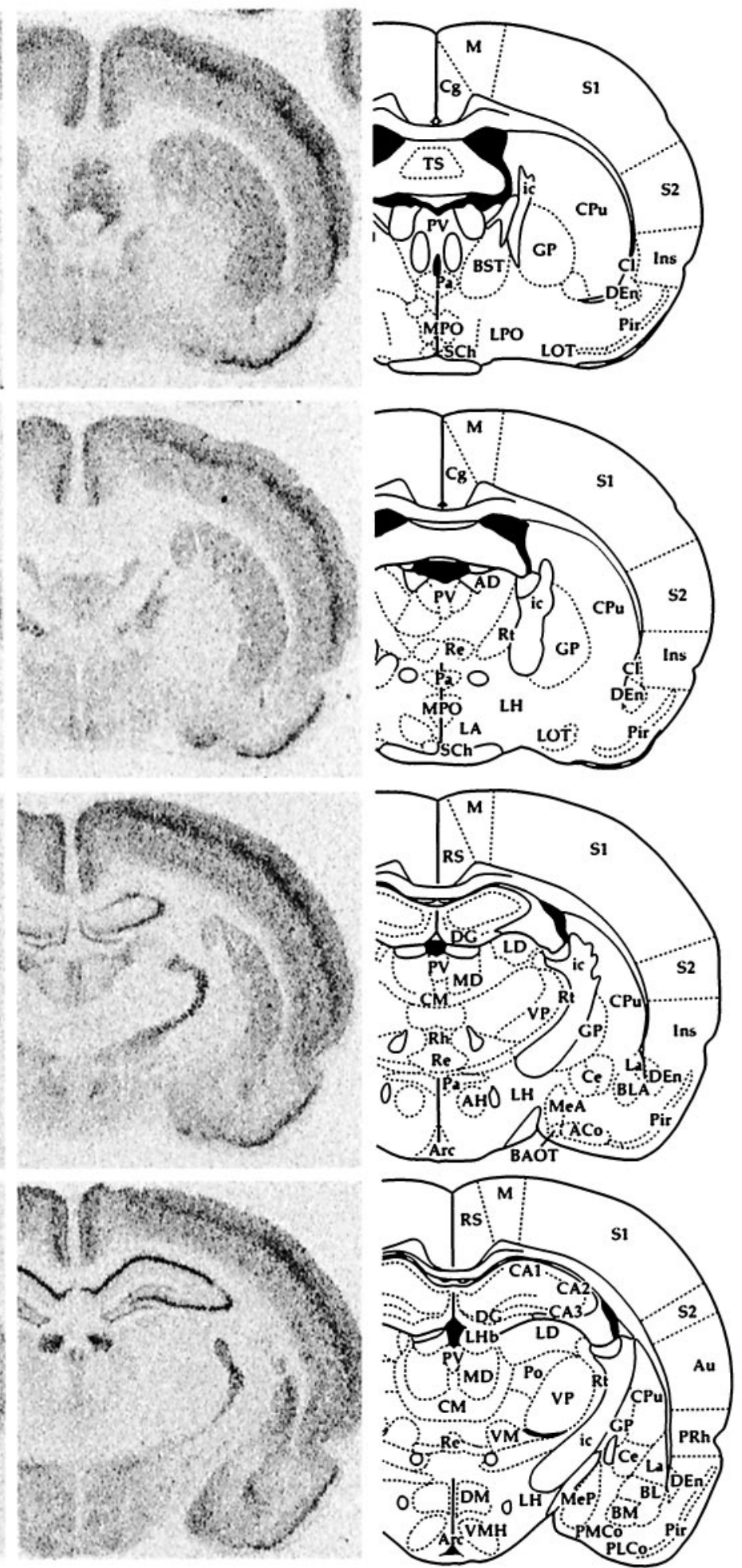

Figure 1 continued.

layer contained moderate levels of $\alpha 1 \mathrm{G}$, whereas $\alpha 1 \mathrm{I}$ was present at very high levels in scattered members of this cell population (Fig. 2).

Moderate to high levels of message were also found for all three genes in olfactory cortical structures, including the anterior ol- factory nucleus (AO; Fig. $1 A$ ) and piriform cortex (Pir; Fig. $1 B-I$; see below). The olfactory tubercle, by contrast, had an expression pattern that was more reminiscent of the striatum (see below) insofar as it contained little expression of $\alpha 1 \mathrm{G}$ mRNA (Figs. $1 B-D, 2)$. Instead, it contained very high levels of $\alpha 1 \mathrm{H}$ in the 
$\alpha 1 G$
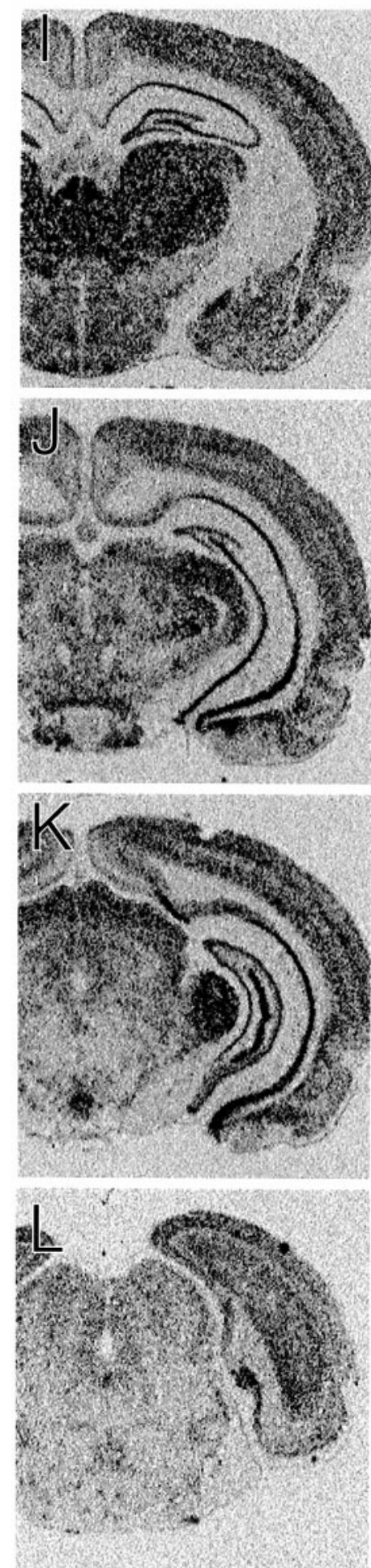

$\alpha 1 \mathrm{H}$
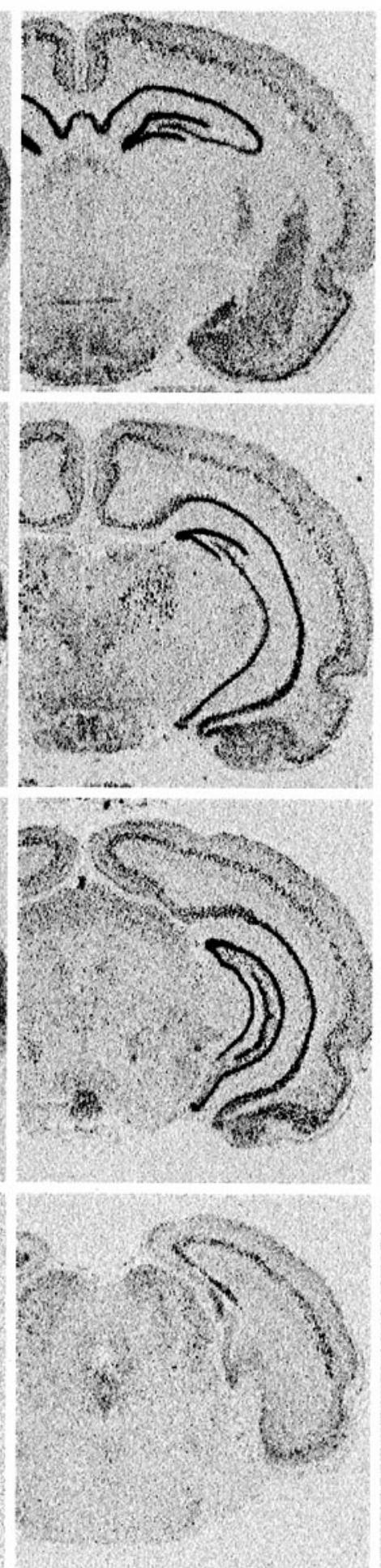

$\alpha 1 \mathrm{I}$
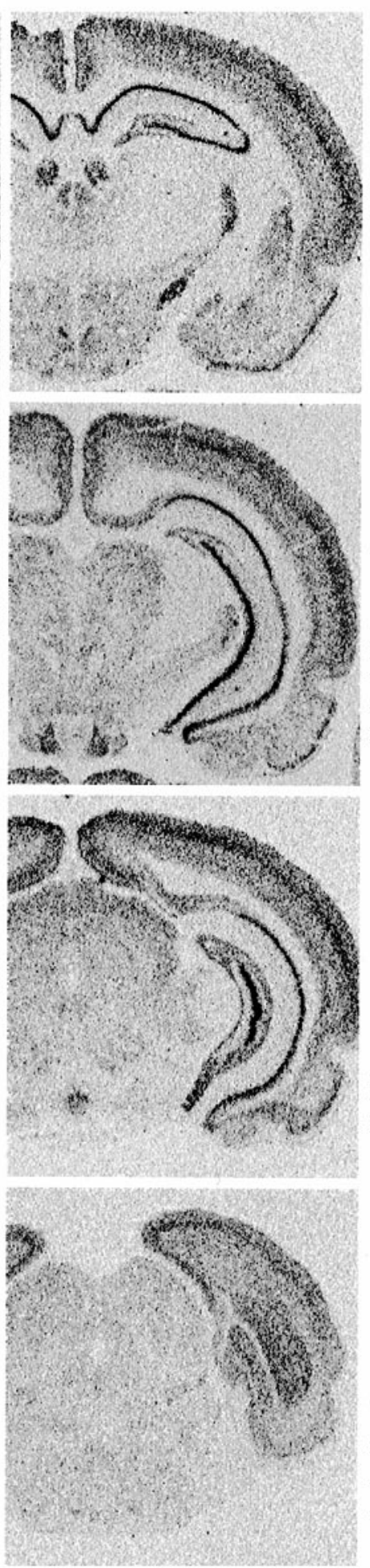
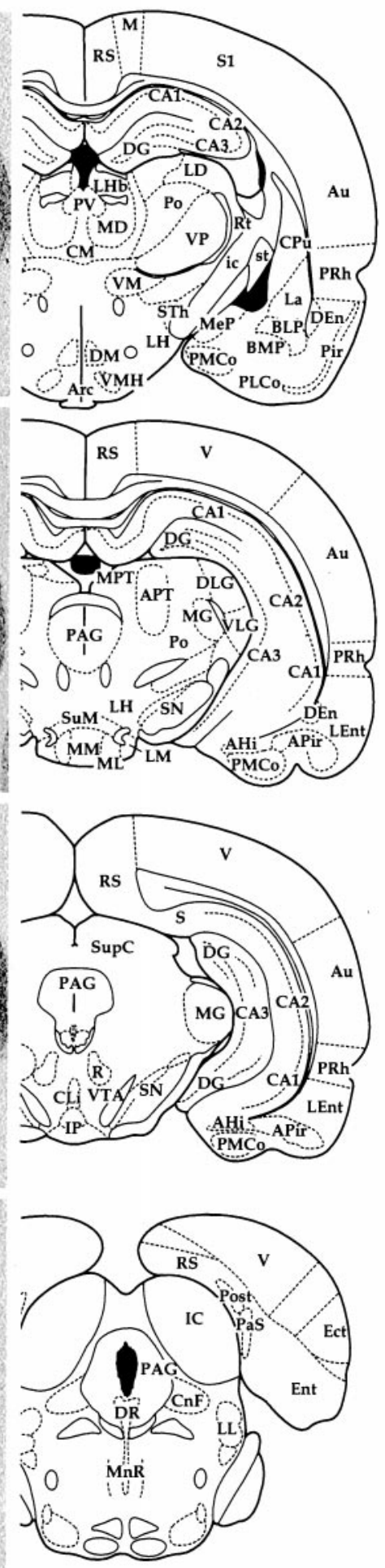

Figure 1 continued.

dense cellular layer as well as very high levels of $\alpha 1 \mathrm{H}$ and $\alpha 1 \mathrm{I}$ in the cellular islands of Calleja.

\section{Basal forebrain}

$\alpha 1 \mathrm{H}$ and $\alpha 1 \mathrm{I}$ transcripts were both present throughout the striatum $(\mathrm{CPu}$; Figs. $1 C-I, 4)$ and the accumbens nucleus (Acb; Fig.
$1 B, C) . \alpha 1 \mathrm{H}$ was detected at moderate levels in these structures, whereas $\alpha 1$ I distribution was mixed: it was found at barely detectable levels in the accumbens and the medial striatum, but it displayed moderate levels at the lateral and caudal edges of the striatum. $\alpha 1 \mathrm{G}$ mRNA was generally undetectable in these struc- 


\section{$\alpha 1 G$}
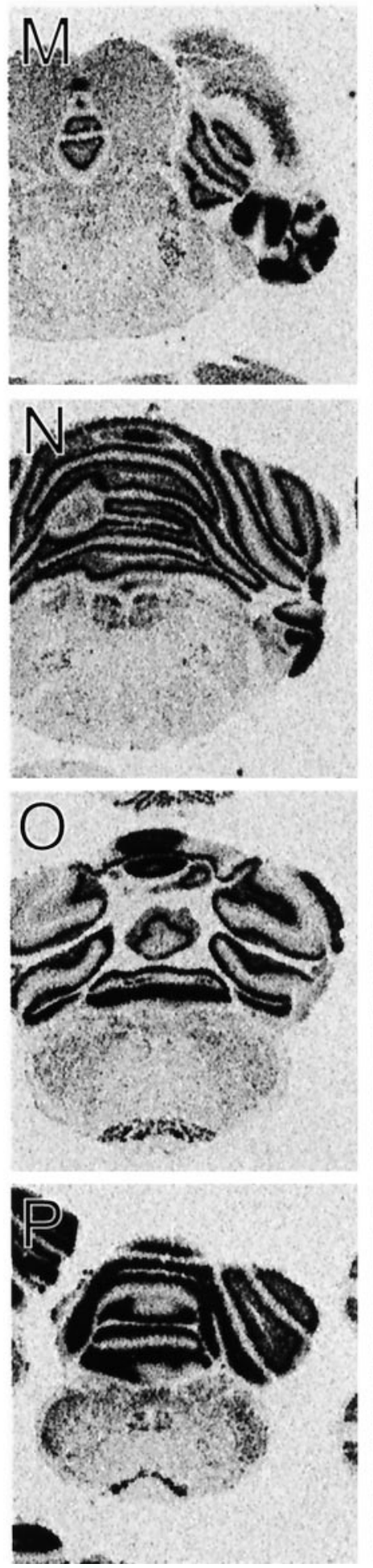

$\alpha 1 \mathrm{H}$
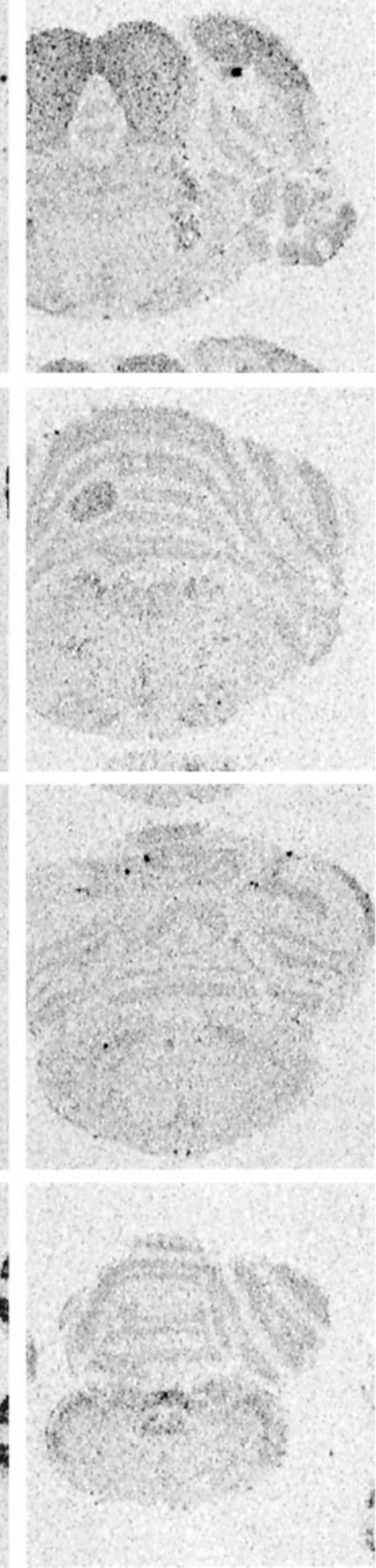

$\alpha 1 \mathrm{I}$
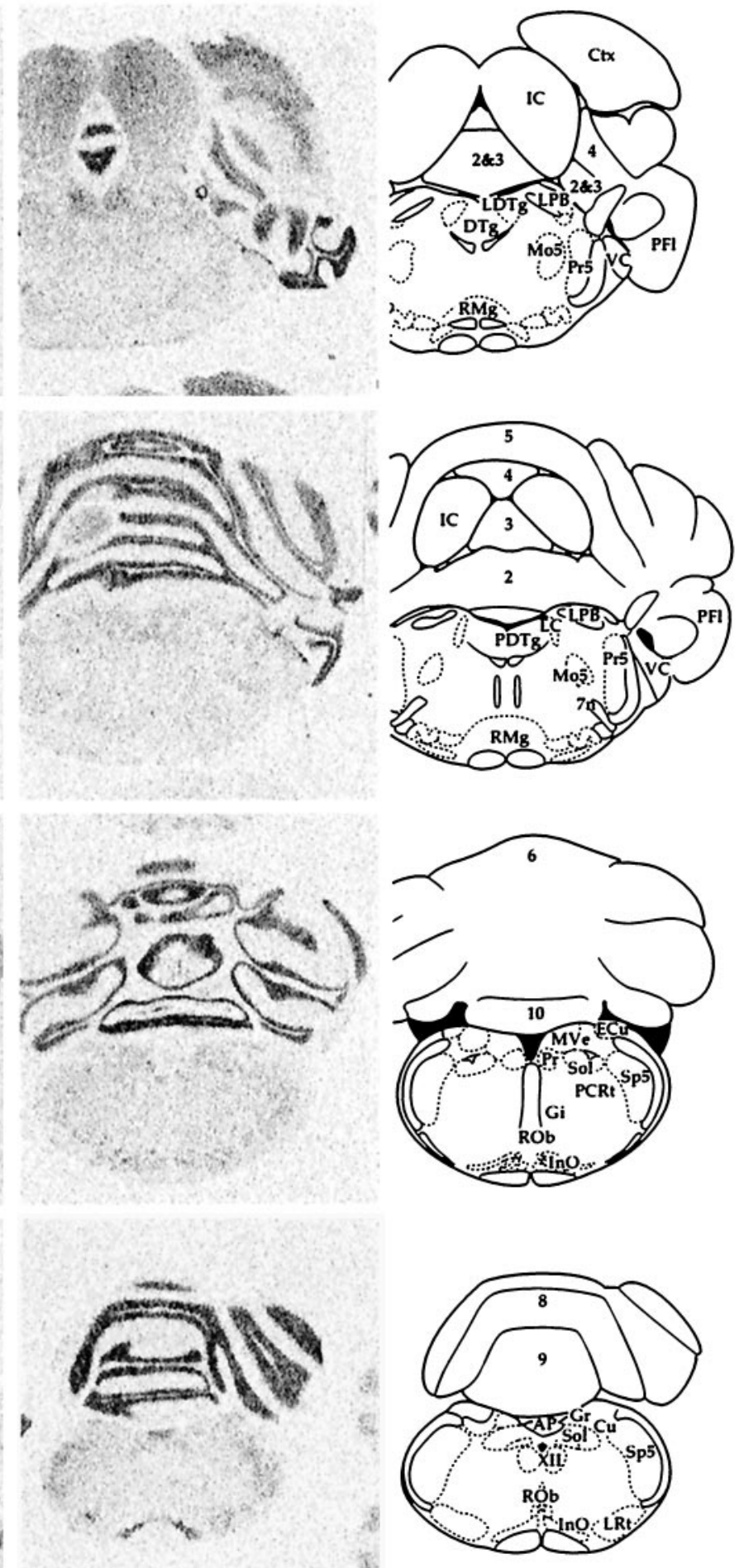

Figure 1 continued.

tures, although scattered cells were labeled: these were more evident medially at the edge of the globus pallidus (GP), a nucleus that was not marked by expression of any of the transcripts (Fig. $1 E-H)$. Another basal ganglia structure, the subthalamic nucleus (STh; Fig. 1I) contained high levels of $\alpha 1 \mathrm{I}$, moderate levels of $\alpha 1 \mathrm{G}$, and only scattered expression of $\alpha 1 \mathrm{H}$.
In the septum (Fig. $1 C-E$ ), labeling was moderate for $\alpha 1 \mathrm{G}$ in the dorsal and ventral part of the lateral septum (LSD, LSV) and low in the intermediate part (LSI) and in the medial septum (MS). $\alpha 1 \mathrm{H}$ labeling was found at low levels in all parts of the lateral and medial septum and absent in the triangular septum (TS). Labeling for $\alpha 1 \mathrm{I}$ was opposite to that of $\alpha 1 \mathrm{H}$; it was not 


\begin{tabular}{|c|c|c|c|}
\hline Brain region & $\alpha 1 \mathrm{G}$ & $\alpha 1 \mathrm{H}$ & $\alpha 1 \mathrm{I}$ \\
\hline \multicolumn{4}{|l|}{ Olfactory system } \\
\hline \multicolumn{4}{|l|}{ Olfactory bulb } \\
\hline Glomerular layer & + & bt & +++ \\
\hline Granule cell layer & ++++ & ++++ & ++++ \\
\hline Anterior olfactory nucleus & +++ & ++ & ++ \\
\hline Olfactory tubercle & + & +++++ & + \\
\hline Islands of Calleja & + & +++++ & +++++ \\
\hline \multicolumn{4}{|l|}{ Basal forebrain } \\
\hline Striatum & bt & ++ & $+/++$ \\
\hline Accumbens & bt & ++ & + \\
\hline Globus pallidus & bt & bt & bt \\
\hline Subthalamic nucleus & ++ & $\mathrm{bt} /+$ & +++ \\
\hline Septum/diagonal band & $+/++$ & $\mathrm{bt} /+$ & $\mathrm{bt} /+$ \\
\hline Indusium griseum & + & ++++ & bt \\
\hline Bed nucleus of the stria terminalis & $+/+++++$ & $+/++$ & $\mathrm{bt} /+$ \\
\hline Claustrum & +++++ & bt & + \\
\hline \multicolumn{4}{|l|}{ Amygdala } \\
\hline Central nucleus & $+/++$ & + & bt \\
\hline Medial nucleus & $++/+++$ & $+/++$ & $\mathrm{bt} /+$ \\
\hline Lateral nucleus & $+1++$ & + & + \\
\hline Basolateral/basomedial nuclei & ++ & + & + \\
\hline Cortical amygdaloid nuclei & $+/+++$ & ++ & + \\
\hline Nucleus of the lateral olfactory tract & ++++ & +++ & ++ \\
\hline Amygdalohippocampal area & +++ & ++ & + \\
\hline Amygdalopiriform transition area & ++ & ++ & + \\
\hline \multicolumn{4}{|l|}{ Cerebral cortex } \\
\hline Neocortex & & & \\
\hline Layers II/III & ++ & $\mathrm{bt} /+$ & + \\
\hline Layer IV & +++ & bt & ++ \\
\hline Layer V & ++ & ++ & + \\
\hline Layer VI & $++/+++$ & bt & + \\
\hline Piriform cortex & $++/+++$ & $+++/$ bt & $+++/$ bt \\
\hline Tenia tecta & ++++ & +++ & +++ \\
\hline Hippocampus & & & \\
\hline Pyramidal cell layers & & & \\
\hline Field CA1 & +++ & ++++ & +++ \\
\hline Field CA2 & ++ & ++++ & ++ \\
\hline Field CA3 & +++ & +++ & ++++ \\
\hline Granule cell layer of the dentate gyrus & ++ & +++++ & + \\
\hline Polymorph layer of the dentate gyrus & ++ & ++ & ++ \\
\hline Thalamus & & & \\
\hline Principal relay nuclei & +++ & bt & $\mathrm{bt} /+$ \\
\hline Intralaminar nuclei & $+++++/+++$ & bt & $\mathrm{bt} /+$ \\
\hline Geniculate nuclei & ++ & bt & $\mathrm{bt} /+$ \\
\hline Reticular thalamic nucleus & bt & ++ & +++ \\
\hline Lateral habenular nucleus & $+/+++$ & bt & $++/+++$ \\
\hline Hypothalamus & & & \\
\hline Preoptic nuclei & $++/+++$ & + & + \\
\hline Suprachiasmatic nucleus & $++/+++$ & + & + \\
\hline Supraoptic nucleus & + & bt & bt \\
\hline Lateral hypothalamic area & + & + & bt \\
\hline Paraventricular nucleus & + & + & bt \\
\hline Arcuate nucleus & ++ & + & + \\
\hline Dorsomedial/ventromedial nuclei & $++/+++$ & $+/++$ & + \\
\hline Mammillary nuclei & $+1++$ & $+1++$ & $+1++$ \\
\hline Mibrain and pons & & & \\
\hline Superior/inferior colliculus & $++/+$ & + & + \\
\hline Periaqueductal gray & ++ & + & bt \\
\hline Tegmental nuclei & $+++1+$ & bt & $\mathrm{bt} /+$ \\
\hline Raphe nuclei & + & $\mathrm{bt} /+$ & bt \\
\hline Substantia nigra & $\mathrm{bt} /+$ & $\mathrm{bt} /+$ & bt \\
\hline Interpeduncular nucleus & ++ & ++ & + \\
\hline Parabrachial nuclei & $++/+$ & + & bt \\
\hline Cerebellum and inferior olive & & & \\
\hline Granule cell layer & & & \\
\hline Anterior & + & bt & ++ \\
\hline Posterior & ++++ & bt & ++ \\
\hline Purkinje cell layer & +++++ & bt & bt \\
\hline Molecular layer & + & bt & bt \\
\hline Deep cerebellar nuclei & + & bt & bt \\
\hline Inferior olive & +++++ & $\mathrm{bt}$ & $\mathrm{bt} /++$ \\
\hline Medulla and spinal cord & & & \\
\hline Spinal trigeminal nuclei & $++/+$ & $\mathrm{bt} /+$ & $\mathrm{bt} /+$ \\
\hline Nucleus of the solitary tract & ++ & + & bt \\
\hline Cochlear nuclei & $+++1++$ & $\mathrm{bt} /+$ & $\mathrm{bt} /+$ \\
\hline Gracile/cuneate nuclei & $++/+$ & + & bt \\
\hline Somatic motor neurons & ++ & + & bt \\
\hline Area postrema & +++ & + & + \\
\hline Reticular fields & $\mathrm{bt} /+$ & bt & $\mathrm{bt} /+$ \\
\hline Other & & & \\
\hline Pituitary & + & +++ & + \\
\hline Pineal gland & + & ++++ & bt \\
\hline Sensory ganglia & + & ++++ & $++/+$ \\
\hline Superior cervical ganglia & + & bt & bt \\
\hline
\end{tabular}

In situ hybridization signals were determined based on relative optical density of film autoradiograms, as well as silver grain density over cells from emulsion-dipped sections.

+++++ , Highest levels of labeling; ++++ , very high; +++ , high; ++ , moderate; + , low levels; bt, below the threshold limit for detection.

Note the heterogeneity of labeling within a number of regions; see corresponding sections in Results for details. detected in the lateral and medial septum, but it was present in low amounts in the triangular septum. This region is traversed by a cortical structure, the indusium griseum (IG; Fig. 1C), which had very high levels of $\alpha 1 \mathrm{H}$ as well as low levels of $\alpha 1 \mathrm{G}$.

The BST (Fig. 1D,E) displayed expression for all three genes, but only in the medial edge of the posterior region of the nucleus. In this restricted area, $\alpha 1 \mathrm{G}$ expression was quite high, $\alpha 1 \mathrm{H}$ was moderate, and $\alpha 1 \mathrm{I}$ was low. In the rest of the nucleus, levels of $\alpha 1 \mathrm{G}$ and $\alpha 1 \mathrm{H}$ expression were low, and $\alpha 1 \mathrm{I}$ expression was not detected. Another basal forebrain structure, the claustrum $(\mathrm{Cl}$; Fig. $1 B-F)$, also had prominent $\alpha 1 \mathrm{G}$ expression along with low levels of $\alpha 1 \mathrm{I}$.

\section{Amygdala}

In the amygdala, $\alpha 1 \mathrm{G}$ and $\alpha 1 \mathrm{H}$ were predominant, with $\alpha 1 \mathrm{I}$ mRNA expressed at low levels in most nuclei (Fig. $1 G-K$ ). Highest levels of all three genes were found in the nucleus of the lateral olfactory tract (LOT; Fig. $1 F$ ) and the related bed nucleus of the accessory olfactory tract (BAOT; Fig. $1 G$ ). In the central nucleus (Ce; Fig. $1 G, H$ ) and the lateral nucleus (La; Fig. $1 G-I$ ), $\alpha 1 \mathrm{H}$ expression was uniformly low, but $\alpha 1 \mathrm{G}$ expression was varied; it was higher in medial portions of the central nucleus and in lateral portions of the lateral nucleus. In the medial amygdala, by contrast, expression for all three genes was mixed; it was higher in the posterior part (MeP; Fig. $1 H, I)$ than in the anterior part (MeA; Fig. $1 G$ ). Expression for $\alpha 1 \mathrm{G}$ and $\alpha 1 \mathrm{H}$ was most evident in the caudal tip of this nucleus, as shown in Figure $1 I$.

\section{Hippocampal formation}

In many CNS regions, the hybridization levels of the $\alpha 1 \mathrm{G}$ probes tended to be higher than those of the other two sets of probes. Such was not the case for the hippocampal formation (Fig. $1 G-L$, 3 ), where labeling intensities were more equivalent between the three sets of probes. Pyramidal cells in the hippocampus had moderate to high levels of all three transcripts, whereas $\mathrm{Ca}_{\mathrm{V}} \mathrm{T}$ expression in the nonpyramidal cell layers of Ammon's Horn was, for the most part, restricted to $\alpha 1 \mathrm{G}$. In the granule cell layer of the dentate gyrus, $\alpha 1 \mathrm{H}$ expression was predominant and extremely high. In contrast, dentate gyrus polymorph cells had labeling that was more closely matched between the three sets of probes.

\section{Cerebral cortex}

All three transcripts were present in the cerebral cortex, as shown in Figures $1 A-L$ and $4, \alpha 1 \mathrm{G}$ and $\alpha 1 \mathrm{I}$ were present fairly uniformly in all cell layers, the major exception being layer IV, where both transcripts were detectable in more cells. In addition, in the ventral part of the cortex just dorsal to the claustrum, a band of neurons that was intensely labeled with the probes for $\alpha 1 \mathrm{G}$ was present in the deepest part of layer VI. These intensely labeled cells appeared to be restricted to the insular/perirhinal cortices (Ins, Fig. $1 B-G$; PRh, Fig. $1 H-K$ ) and secondary somatosensory areas (e.g., Fig. $1 E$ ). With respect to particular cell types, probes for $\alpha 1 \mathrm{G}$ and $\alpha 1 \mathrm{I}$ labeled both large (presumably pyramidal) and small (presumably granule) neurons. However, this labeling was not uniform, and in some cells expression was not detected. Thus, no clear preference emerged for expression of either one of these transcripts by specific types of cortical neurons.

Such a general distribution in the neocortex was not the case for $\alpha 1 \mathrm{H}$. It was seen at very high levels in a subset of layer $\mathrm{V}$ pyramidal neurons; otherwise it was only present at very low levels in the externalmost cellular layer (layer II) and was not detected in layers IV and VI. The $\alpha 1 \mathrm{H}$-expressing pyramidal 


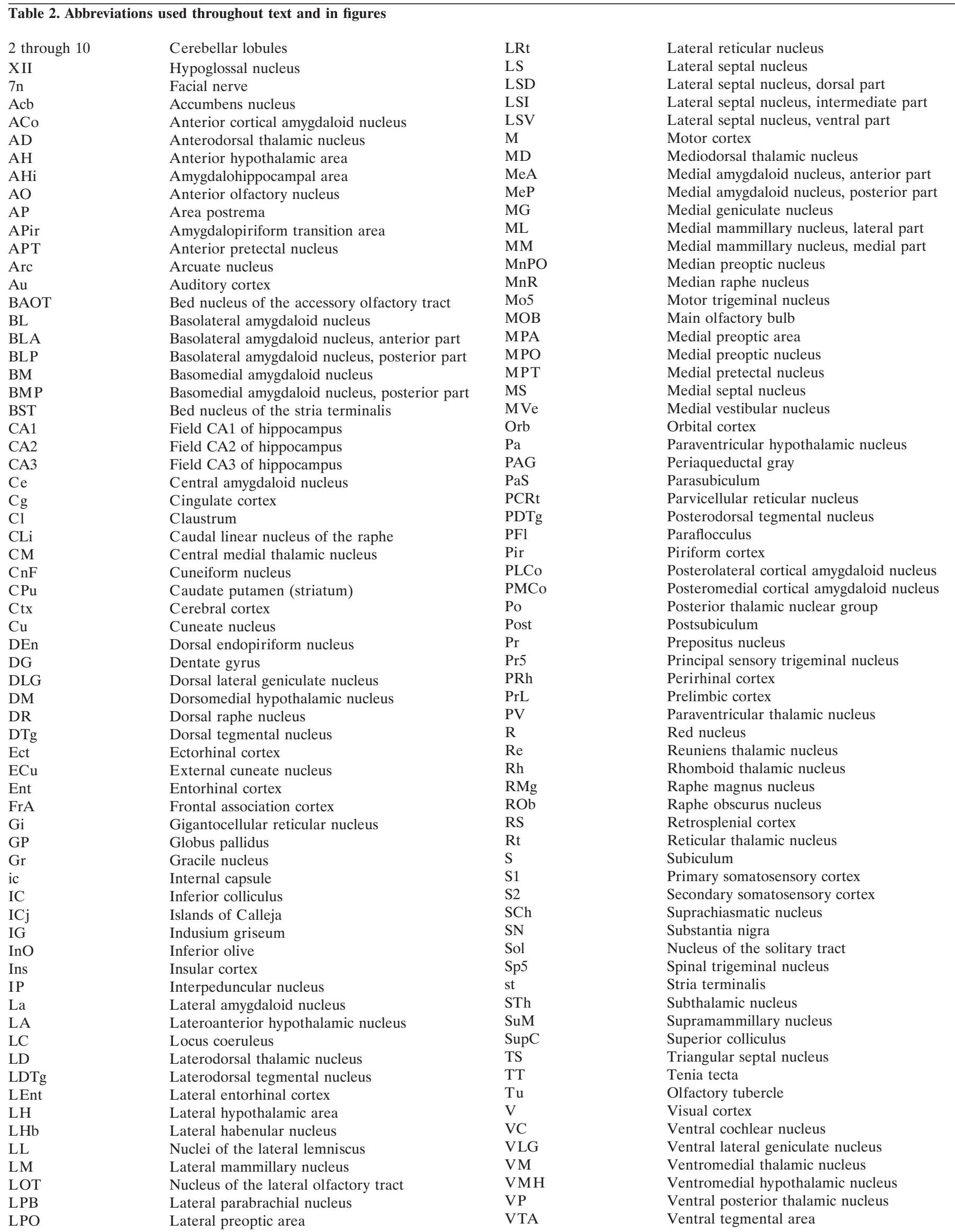


neurons were predominantly found in the deeper part of layer $\mathrm{V}$, although not every large neuron at this level was labeled.

Two rostral cortical structures expressed all three transcripts at high levels. One was the TT (Fig. $1 B$ ). The other structure, the Pir (Fig. $1 B-I$ ), had mixed expression levels of all three genes. Both $\alpha 1 \mathrm{H}$ and $\alpha 1 \mathrm{I}$ were present in high amounts in the superficial neurons of this cortical region but were not detected in deeper layers. On the other hand, $\alpha 1 \mathrm{G}$ mRNA was expressed in moderate amounts in the external layer but at much higher levels in the deeper layers, especially the dorsal endopiriform nucleus (DEn; Fig. $1 C-J)$.

\section{Thalamus}

The thalamus (Figs. $1 E-K, 5$ ) was characterized by high levels of expression of $\alpha 1 \mathrm{G}$ in thalamocortical relay nuclei. In many of these nuclei, including the medial dorsal (MD), the ventral anterior (VA), the ventral and posterior relay nuclei (Po, VM, and $\mathrm{VP}$ ), and the medial and dorsal lateral geniculate nuclei (MG and DLG), detectable expression was limited to $\alpha 1 \mathrm{G}$. Low levels of $\alpha 1$ I were seen in the anterior dorsal nucleus (AD; Fig. $1 F)$ and the rostral part of the lateral dorsal nucleus (LD; Fig. $1 G$ ); low to moderate levels were seen in the ventral lateral geniculate nucleus (VLG; Fig. $1 J$ ). Expression of $\alpha 1 \mathrm{H}$ in relay nuclei was limited to some of the large neurons of AD that expressed this transcript at low levels. The intralaminar nuclei, including the central medial nucleus (CM; Fig. $1 G, H)$, paraventricular thalamic nucleus (PV; Fig. $1 F-I$ ), the rhomboid (Rh; Fig. $1 G)$, and reuniens (Re; Fig. $1 G, H)$ nuclei had even higher levels of $\alpha 1 \mathrm{G}$ expression. Low levels of $\alpha 1 \mathrm{I}$ expression also characterized a number of these nuclei (CM, PV, and Rh).

In contrast to the thalamic relay and intralaminar nuclei, the thalamic reticular nucleus, which is composed of GABAergic interneurons that modulate and synchronize thalamic output (for review, see Steriade et al., 1993), had no detectable $\alpha 1 \mathrm{G}$ expression (Fig. 5, left panels). Instead, these neurons expressed high levels of $\alpha 1 \mathrm{I}$ and moderate levels of $\alpha 1 \mathrm{H}$. The lateral habenula (Fig. 5, right panels) had an uneven distribution of $\alpha 1 \mathrm{G}$ and $\alpha 1 \mathrm{I}$; both transcripts were detected at high levels in the rostral portion of the nucleus. Caudally, $\alpha 1 \mathrm{I}$ expression was moderate, and $\alpha 1 \mathrm{G}$ expression was low (Fig. 1, compare $H, I$ ). $\mathrm{Ca}_{\mathrm{V}} \mathrm{T}$ expression was not detected in neurons of the medial habenula, a region characterized by high levels of mRNA encoding $\alpha 1 \mathrm{E}$ (Soong et al., 1993; Williams et al., 1994).

\section{Hypothalamus}

In the hypothalamus, $\alpha 1 \mathrm{G}$ was predominant rostrally. In the preoptic region (Fig. $1 D-F$ ), $\alpha 1 \mathrm{G}$ mRNA levels were higher in medial structures such as the medial preoptic nucleus (MPO) than in their lateral counterparts (e.g., LPO). This medial bias also included the rostral portion of the suprachiasmatic nucleus (SCh; Fig. 1E,F). More caudally, expression levels were mixed. Expression of all three genes was found in both the dorsomedial (DM) and the ventromedial (VMH) nuclei, with high levels of $\alpha 1 \mathrm{G}$ mRNA in the ventrolateral portion of the VMH (Fig. $1 H, I)$. Expression patterns in the mammillary bodies were somewhat complex, with each transcript showing a unique expression pattern (Fig. $1 J)$. In the medial mammillary nucleus, the medial part (MM) showed a predominance of $\alpha 1 \mathrm{H}$ expression, whereas the lateral part (ML) displayed $\alpha 1 \mathrm{G}$ and $\alpha 1 \mathrm{I}$. In the lateral mammillary nucleus (LM), $\alpha 1 \mathrm{G}$ was abundant, with the other two transcripts present only at low levels.
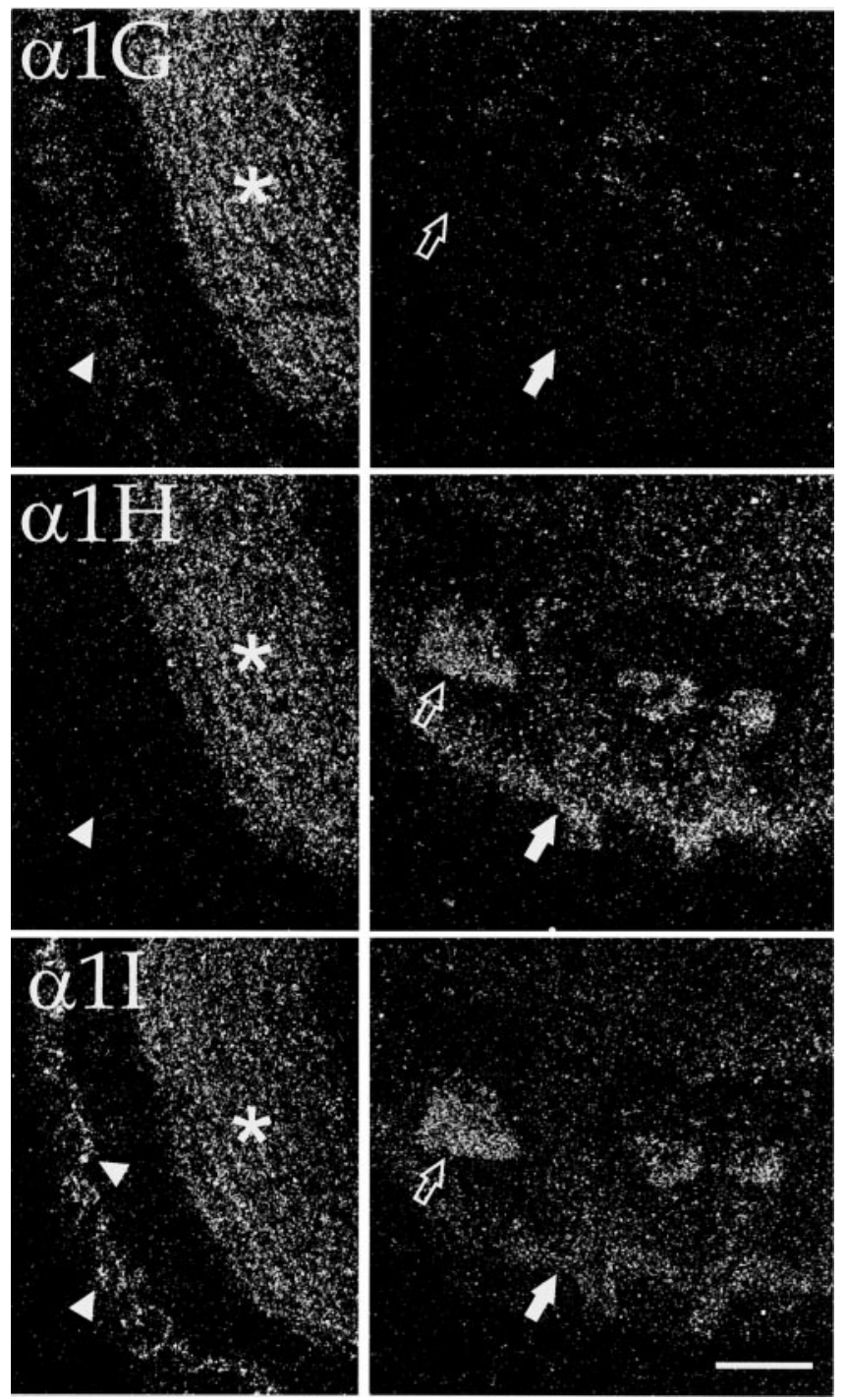

Figure 2. Dark-field micrographs demonstrating cellular labeling of olfactory structures. Slides were exposed to autoradiographic emulsion; silver grains were imaged using dark-field microscopy. Left panels show silver grains over cells of the main olfactory bulb. Note that whereas all three transcripts were present in the granule cell layer (asterisks), labeling of small neurons in the glomerular layer (arrowheads) was limited to $\alpha 1 \mathrm{G}$ and $\alpha 1 \mathrm{I}$. Right panels show the olfactory tubercles. Labeling for $\alpha 1 \mathrm{H}$ and $\alpha 1 \mathrm{I}$ was very high in the cell islands of Calleja (open arrows); labeling was also high for $\alpha 1 \mathrm{H}$ but only moderate for $\alpha 1 \mathrm{I}$ in the dense cell layer of the tubercles (closed arrows). Scale bar, $500 \mu \mathrm{m}$.

\section{Midbrain and pons}

All three transcripts were expressed in the tectum (SupC and IC; Fig. $1 K-M)$, with $\alpha 1 \mathrm{H}$ and $\alpha 1 \mathrm{I}$ at low levels and $\alpha 1 \mathrm{G}$ at low to moderate levels, except in the external gray area of the superior colliculus, where $\alpha 1 \mathrm{G}$ labeling was high (Fig. $1 K$ ). All three transcripts also were found in the pretectal nuclei (MPT and APT; Fig. $1 J)$, which were notable as a result of high $\alpha 1 \mathrm{H}$ labeling in scattered cells of the anterior pretectal nucleus (APT). The periaqueductal gray (PAG; Fig. $1 J-L$ ) had moderate levels of labeling for $\alpha 1 \mathrm{G}$ and low levels of $\alpha 1 \mathrm{H}$. More caudally, the tegmental nuclei ventral to the fourth ventricle (Fig. $1 M, N$ ) were a little more heterogeneous, with $\alpha 1 \mathrm{G}$ mRNA at high levels in the posterodorsal tegmental nucleus (PDTg; Fig. $1 N$ ) and $\alpha 1$ I present in the laterodorsal nucleus (LDTg; Fig. 1M). 

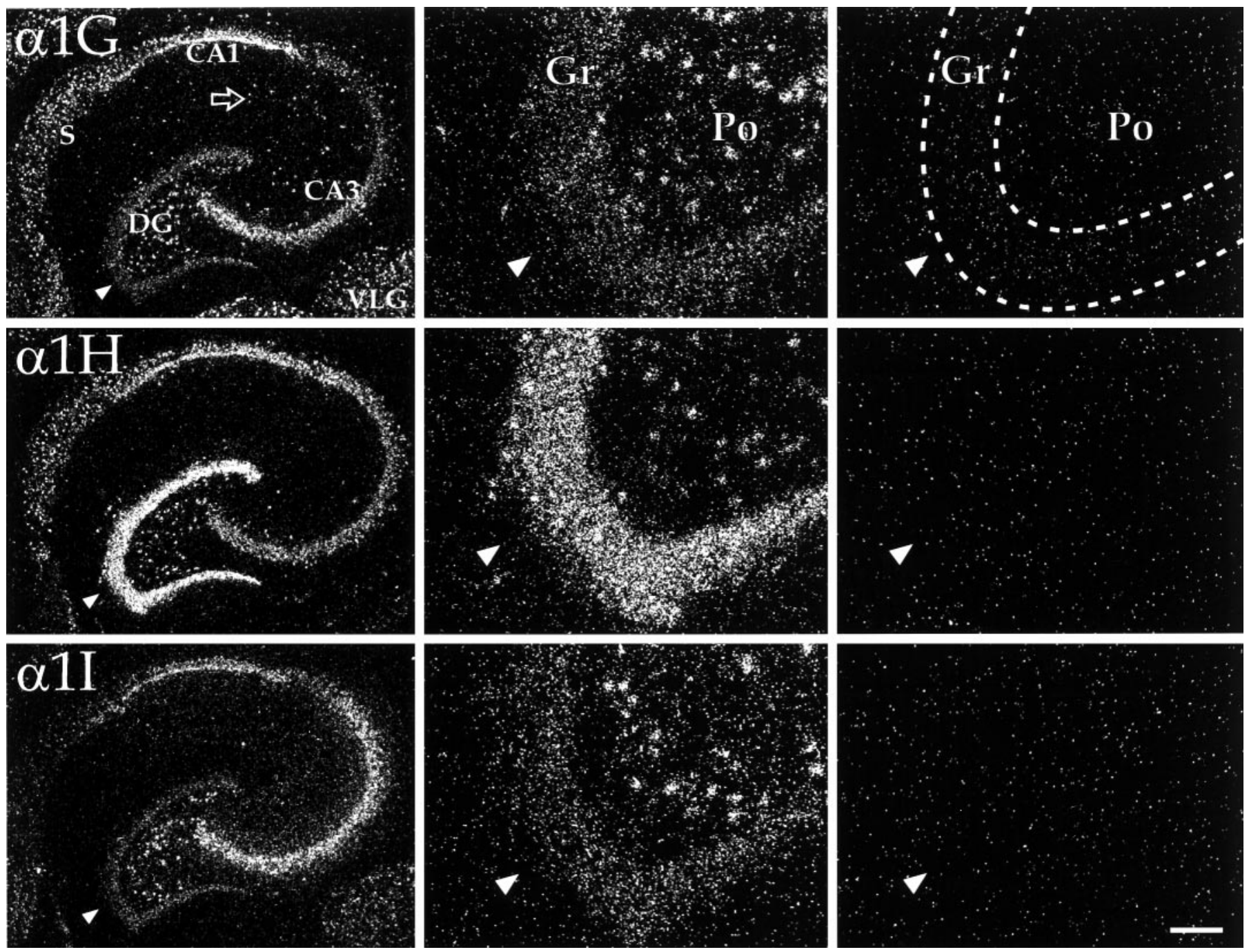

Figure 3. Dark-field micrographs of horizontal sections through the ventral portion of the hippocampus. Left panels show cross sections in the horizontal plane through the ventral hippocampus. Note that whereas all three transcripts were present, each had a different relative distribution through the various hippocampal fields. Fields CA1 and CA3 are indicated, as are the dentate gyrus $(D G)$, the subiculum $(S)$, and the ventral lateral geniculate nucleus $(V L G)$ of the thalamus. Open arrow points to $\alpha 1 \mathrm{G}$-labeled (presumably nonpyramidal) cells in stratum radiatum. The dentate gyrus is shown at higher magnification in the middle panels. Note that the granule cell layer (Gr,arrowheads in all three sets of panels) shows particularly strong labeling for $\alpha 1 \mathrm{H}$, whereas cells of the polymorph layer $(P o)$ show more even levels of the three transcripts. Right panels show images of the dentate gyrus from control sections hybridized in the presence of $\sim 500$-fold excess cold oligonucleotide. Note that this nonspecific labeling was uniformly low. Scale bar, $400 \mu \mathrm{m}$ (left panels); $100 \mu \mathrm{m}$ (middle and right panels).

Labeling for $\alpha 1 \mathrm{G}$ and $\alpha 1 \mathrm{H}$ were found at low levels in the raphe nuclei (Fig. $1 K, L)$. These two transcripts were also found in the substantia nigra (SN; Fig. $1 J, K$ ); in the compact part $\alpha 1 \mathrm{G}$ labeling was moderate and $\alpha 1 \mathrm{H}$ low, whereas the reticular part was for the most part unlabeled, except for some cells that contained $\alpha 1 \mathrm{H}$ (data not shown). All three transcripts were found in the interpeduncular nucleus (IP; Fig. $1 K$ ) with $\alpha 1 \mathrm{G}$ and $\alpha 1 \mathrm{H}$ at moderate levels and $\alpha 1 \mathrm{I}$ at low levels. The lateral parabrachial nucleus (LPB; Fig. $1 M, N$ ) had low levels of $\alpha 1 \mathrm{G}$ and $\alpha 1 \mathrm{H}$, except for the external portion, which had moderate to high levels of $\alpha 1 \mathrm{G}$ (Fig. $1 M$ ). One other area of note was the pontine nuclei (not shown), which had low to moderate levels of both $\alpha 1 \mathrm{G}$ and $\alpha 1 \mathrm{I}$.

\section{Cerebellum and inferior olive}

Expression of $\mathrm{Ca}_{\mathrm{V}} \mathrm{T}$ transcripts in the cerebellum is illustrated in Figures $1 M-P$ and 6. $\alpha 1 \mathrm{G}$ expression was strikingly high in every
Purkinje cell examined, and granule cells were labeled with $\alpha 1 \mathrm{G}$ probes in a rostral-to-caudal gradient of increasing levels of expression (in both the hemispheres and the vermis), as has been seen for a variety of cerebellar markers (Herrup and Kuemerle, 1997). $\alpha 1$ I mRNA also was present in the granule cell layer at moderate levels, although it lacked the graded expression seen for $\alpha 1 \mathrm{G}$. The InO (Figs. $1 O, P, 6)$ also contained $\alpha 1 \mathrm{G}$ and $\alpha 1 \mathrm{I}$ mRNA; in this case $\alpha 1 \mathrm{G}$ was expressed at very high levels throughout the nucleus, whereas $\alpha 1$ I was expressed at moderate levels, but only in caudal olivary neurons.

\section{Medulla and spinal cord}

In the medulla and in the spinal cord, probes for $\alpha 1 \mathrm{G}$ mRNA once again generated a higher signal than did those for $\alpha 1 \mathrm{H}$ and $\alpha 1$ I. Labeling for all three transcripts was sparse or absent in brainstem reticular areas, including those of the midbrain and pons (Fig. $1 L-N)$. In the medullary reticular fields, $\alpha 1 \mathrm{G}$ was 

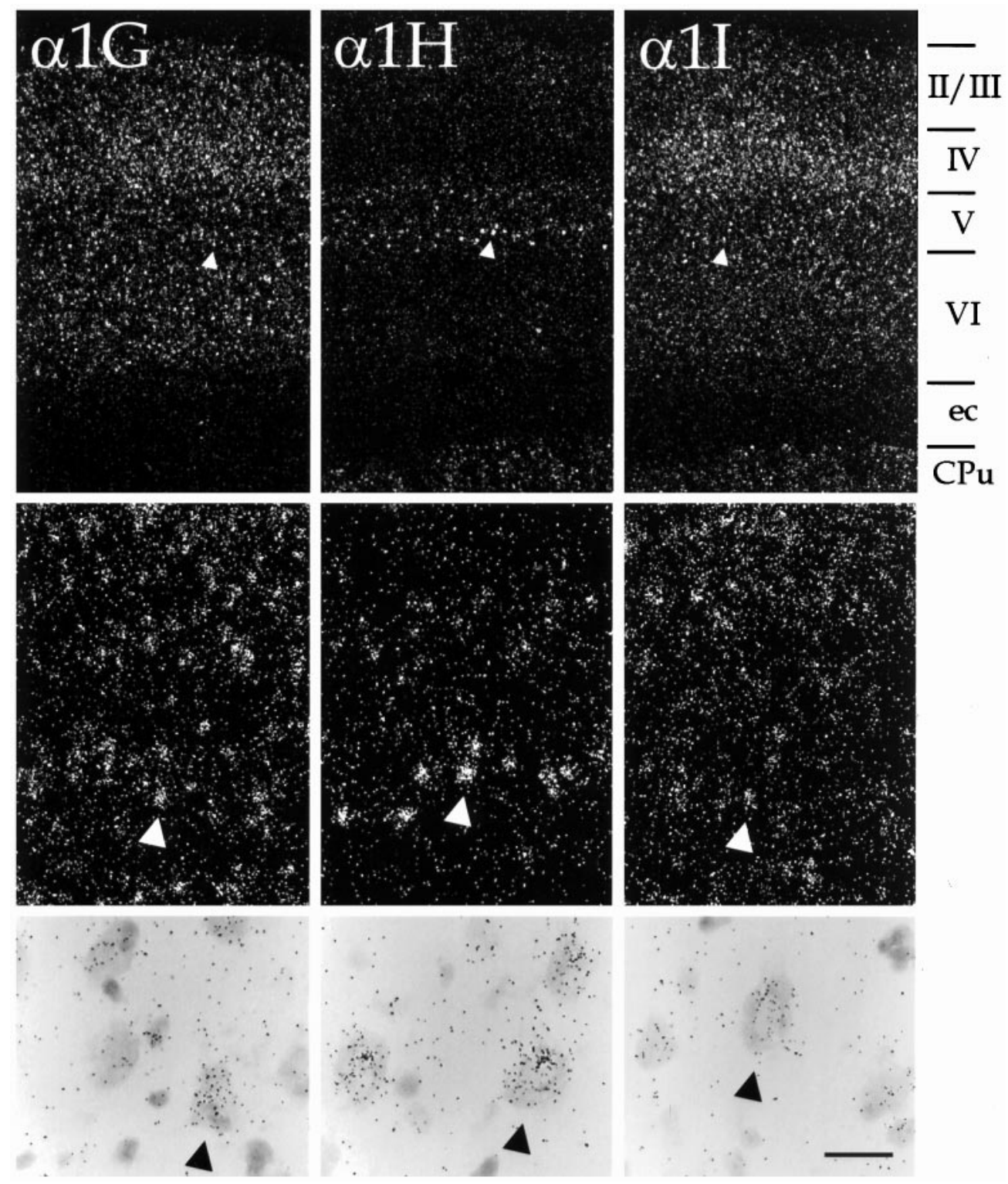

Figure 4. Differential hybridization to neurons in the cerebral cortex. Distribution of $\alpha 1 \mathrm{G}, \alpha 1 \mathrm{H}$, and $\alpha 1 \mathrm{I}$ mRNA in the primary somatosensory cortex is shown at increasing levels of magnification. Top panels demonstrate laminar distribution of labeling; the relevant cortical layers (layers II-VI) are indicated to the right of these panels, as are the external capsule $(e c)$ and the striatum $(C P u) . A r-$ rowheads indicate large (presumably pyramidal) neurons in layer $\mathrm{V}$. The same neurons are depicted at higher magnification in the middle panels (using darkfield optics) and at still higher magnification in bottom panels (using brightfield optics). Note that $\alpha 1 \mathrm{G}$ and $\alpha 1 \mathrm{I}$ were found in all cortical layers, but expression of $\alpha 1 \mathrm{H}$ was for the most part restricted to layer V. Scale bar, $400 \mu \mathrm{m}$ (top panels); $100 \mu \mathrm{m}$ (middle panels); 25 $\mu \mathrm{m}$ (bottom panels). present at low levels in the lateral but not the medial areas (Fig. $1 O$, compare PCRt, Gi); $\alpha 1$ I was found in the lateral reticular nucleus (Fig. $1 P$ ).

All three transcripts were detected in sensory areas. In the spinal trigeminal nucleus (Sp5), the three mRNAs were found at higher levels caudally than rostrally (Fig. 1, compare $O, P$ ). All three also were seen in the dorsal cochlear nucleus (data not shown), but only $\alpha 1 \mathrm{G}$ was present (and at lower levels) in the ventral cochlear nucleus (VC; Fig. $1 M, N$ ). Similarly, all three transcripts were present in the dorsal horn of the spinal cord (Fig. 7). $\alpha 1 \mathrm{G}$ was present at moderate levels; $\alpha 1 \mathrm{H}$ was for the most part restricted to the outermost layers (layers $1-2)$. $\alpha 1$ I was somewhat more evenly distributed at low levels, but it was more prominent in layers 3-4. Only $\alpha 1 \mathrm{G}$ and $\alpha 1 \mathrm{H}$ were detected in the nucleus of the solitary tract (Sol; Fig. 1O,P).

Somatic motor neurons in the brainstem and spinal cord contained $\alpha 1 \mathrm{G}$ and $\alpha 1 \mathrm{H}$ mRNA, at moderate and low levels, respectively (Figs. $1 M, P, 7)$. Other labeled medullary regions included the inferior olive (discussed above) and the area postrema (AP; Fig. 1P); in the AP all three transcripts were found, with $\alpha 1 \mathrm{G}$ at high levels.

\section{Other areas}

In addition to surveying the CNS, we also hybridized the $\mathrm{Ca}_{\mathrm{V}} \mathrm{T}$ probes to sections from the sensory and sympathetic ganglia, specifically the nodose, dorsal root ganglia (DRG) and superior cervical ganglia. High-power bright-field micrographs of sensory neurons of the DRG and nodose ganglia are shown in Figure 7 (middle and left panels). In the DRG, high levels of $\alpha 1 \mathrm{H}$ and moderate levels of $\alpha 1 \mathrm{I}$ mRNA were found in scattered mediumsized neurons, whereas the extremely large neurons were not labeled. The nodose ganglia also contained high levels of $\alpha 1 \mathrm{H}$ mRNA in many neurons, although in contrast to the DRG, there did not appear to be a bias in the size of the labeled neurons. Neurons of the superior cervical ganglia (not shown) only expressed very low levels of $\alpha 1 \mathrm{G}$. We also examined cells of the pituitary and pineal glands. Both of these structures showed high levels of expression of $\alpha 1 \mathrm{H}$ mRNA (data not shown).

\section{DISCUSSION}

We used in situ hybridization to show that three members of a novel family of calcium channels with T-type properties are expressed widely in the CNS and in peripheral neurons, and that 

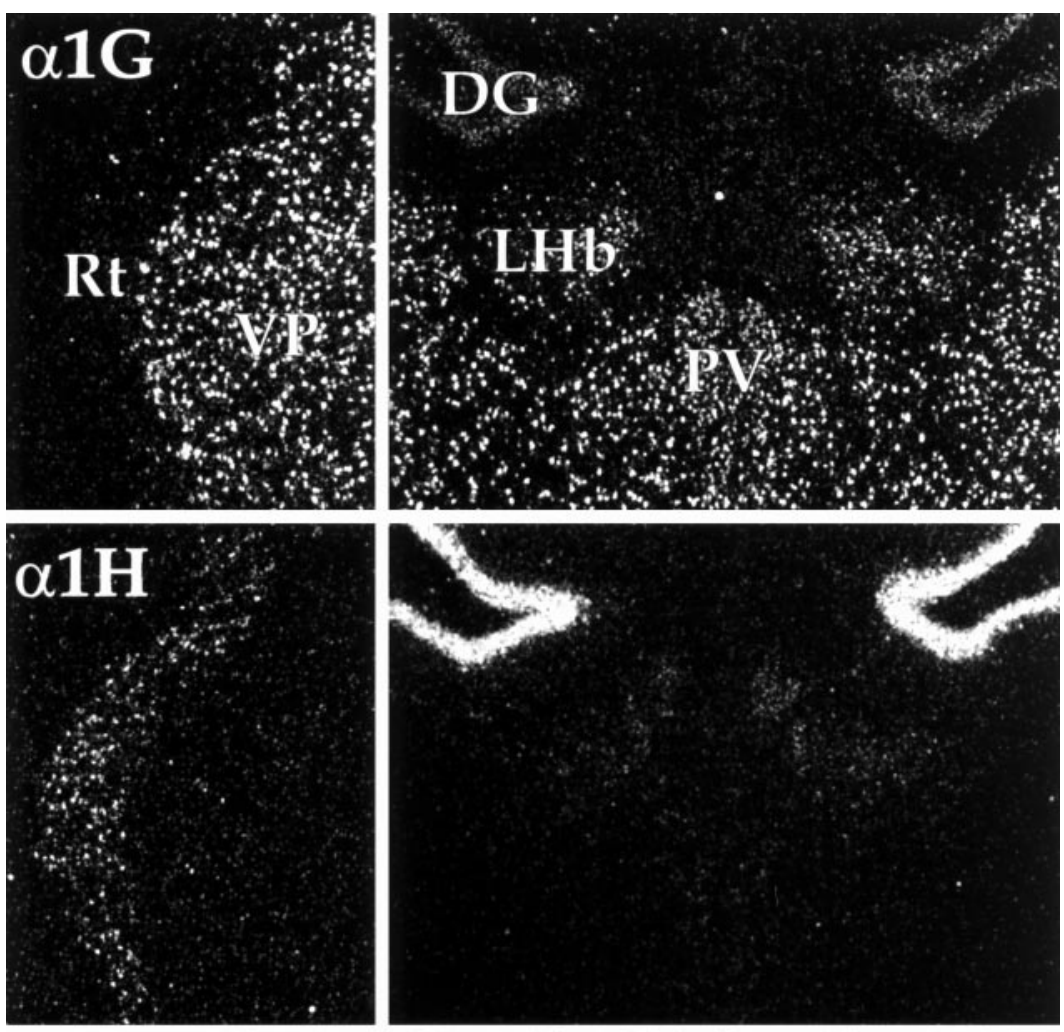

Figure 5. Distribution of $\mathrm{Ca}_{\mathrm{V}} \mathrm{T}$ expression in the thalamus. Left panels show differential labeling of the thalamic reticular nucleus $(R t)$ and ventral posterior thalamic nucleus $(V P)$. Note that neurons of the reticular nucleus contained $\alpha 1 \mathrm{H}$ and $\alpha 1 \mathrm{I}$ mRNA, whereas $\alpha 1 \mathrm{G}$ expression was limited to thalamic relay nuclei, including VP. Right panels show labeling in the habenulae and midline thalamic nuclei. Neurons of the lateral habenular nucleus $(L H b)$ expressed $\alpha 1 \mathrm{G}$ and $\alpha 1$ I mRNA (see Results for details). $D G$, Dentate gyrus; $P V$, paraventricular thalamic nucleus. Scale bar, $250 \mu \mathrm{m}$.
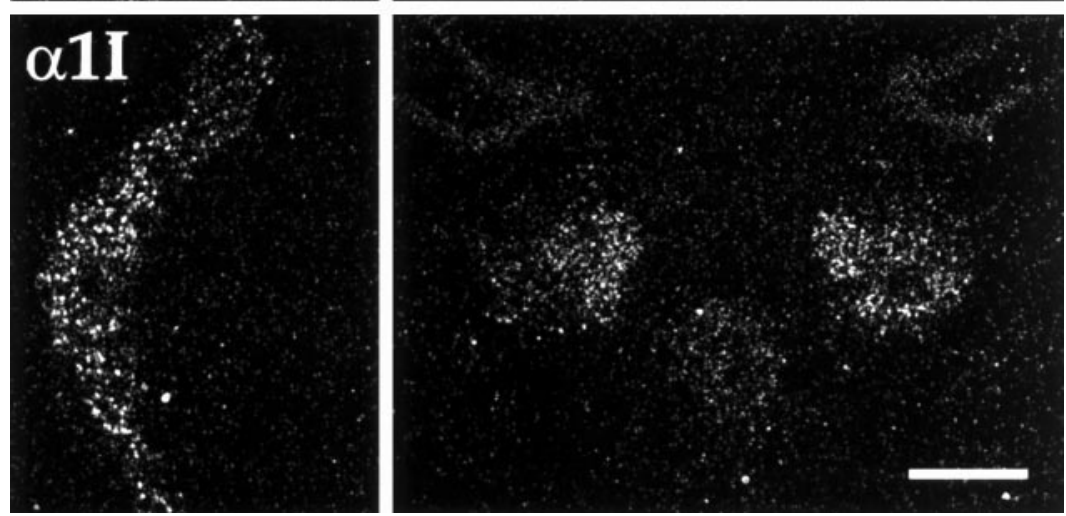

each of these three transcripts has a unique pattern of distribution. Our results reveal that expression of these genes is prominent in a number of brain areas where T-type currents have been recorded and absent in specific regions believed to be devoid of these currents. Furthermore, our data are in accord with the hypothesis that differential expression of specific $\mathrm{Ca}_{\mathrm{V}} \mathrm{T}$ subtypes may account for at least some of the heterogeneity observed in CNS T-type calcium currents.

\section{$\mathrm{Ca}_{\mathbf{v}} \mathrm{T}$ transcripts are expressed in cells with prominent T-type currents}

As anticipated, we detected robust expression of $\mathrm{Ca}_{\mathrm{V}} \mathrm{T}$ mRNA in areas where prominent T-type calcium currents have been observed. For example, we found expression of all three transcripts in the thalamus, where the role of T-type calcium channels has been studied extensively (for review, see Steriade et al., 1993). We found $\alpha 1 \mathrm{G}$ mRNA to be predominant in thalamocortical relay areas but absent in the thalamic reticular nucleus, which instead expressed high and moderate levels of $\alpha 1 \mathrm{I}$ and $\alpha 1 \mathrm{H}$ mRNA, respectively. It is believed that the differences in the characteristics of T-type currents in these two cell types (discussed below) are important for the generation of synchronized thalamocortical rhythms (McCormick and Bal, 1997).

Another region classically associated with prominent T-type calcium current is the InO, where we found $\alpha 1 \mathrm{G}$ mRNA in great abundance. LVA currents in these neurons contribute to oscillations that support the coordination of synchronous rhythmic firing (Manor et al., 1997). These neurons make monosynaptic contacts with Purkinje cells of the cerebellum, and their synchronous activity is believed to play a prominent role in the organization of cerebellar output (Welsh et al., 1995). It is worth pointing out that we found a heterogeneous distribution of $\mathrm{Ca}_{\mathrm{V}} \mathrm{T}$ transcripts in the InO. Expression in the rostral part of the nucleus was restricted to $\alpha 1 \mathrm{G}$, whereas caudal expression consisted of both $\alpha 1 \mathrm{G}$ and $\alpha 1 \mathrm{I}$ (Figs. 1O,P, 6). It remains to be determined how this differential distribution of $\mathrm{Ca}_{\mathrm{V}} \mathrm{T}$ expression in the inferior olive might contribute to the functional organization of olivocerebellar processing.

In addition to $\alpha 1 \mathrm{G}$ and $\alpha 1 \mathrm{I}$, we also found abundant $\alpha 1 \mathrm{H}$ mRNA in regions commonly associated with prominent T-type calcium currents. For example, we found high levels of this 

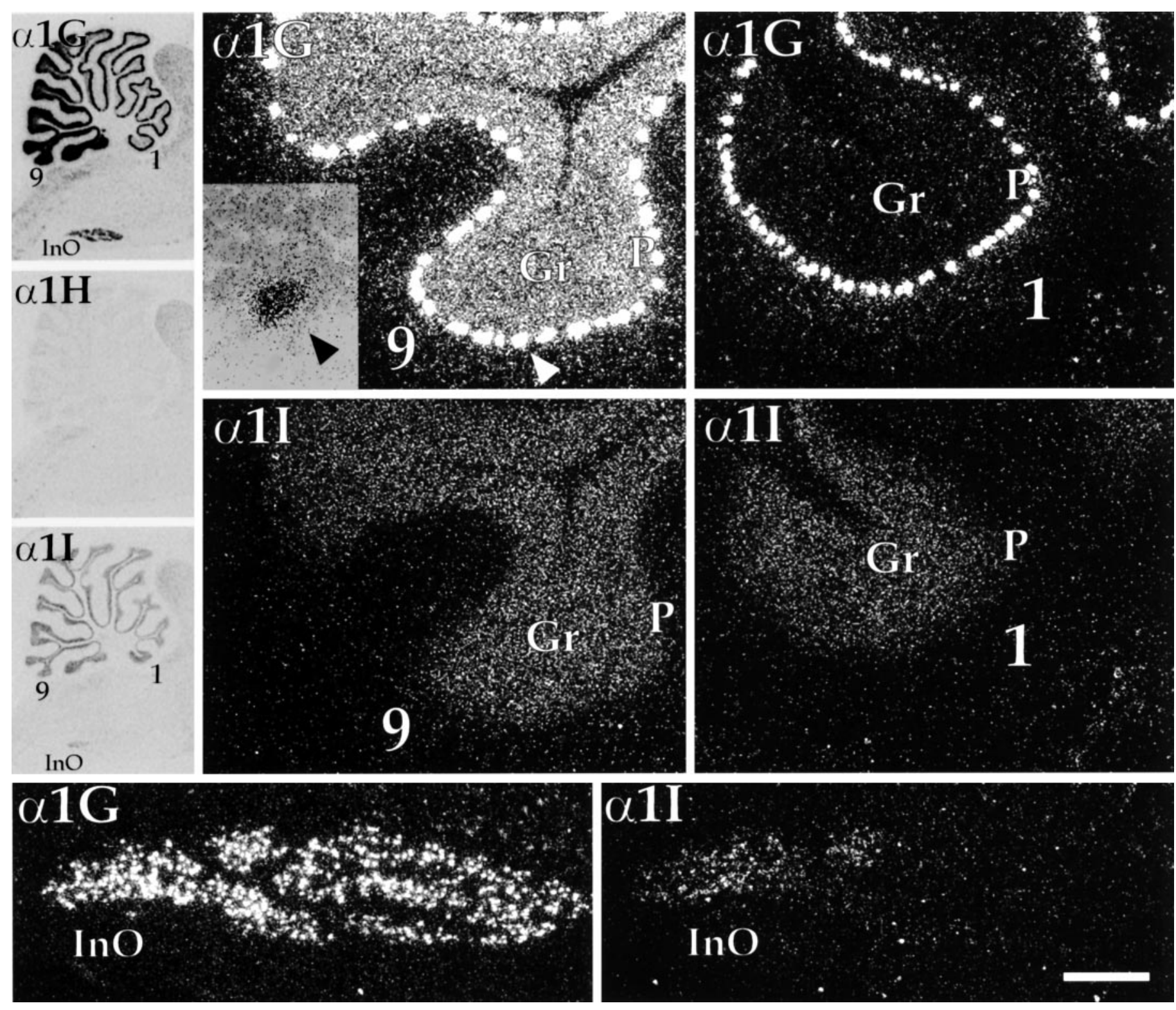

Figure 6. Parasagittal sections demonstrating labeling of the cerebellum and inferior olivary nucleus. Left panels show bright-field images of film autoradiograms exposed to sagittal sections through the brainstem and cerebellum. Lobules 9 and 1 of the cerebellar vermis are indicated and correspond to higher magnification dark-field micrographs of emulsion-dipped sections shown on the right. Note that for $\alpha 1 \mathrm{G}$, the granule cell layer $(G r)$ of the cerebellum displayed a rostrocaudal gradient of expression, with lobule 9 labeled intensely and lobule 1 showing very low levels. In contrast, expression of $\alpha 1 \mathrm{I}$ in the granule cell layer was fairly uniform throughout the cerebellum and showed similar levels in both lobules. Probes for $\alpha 1 \mathrm{G}$ labeled Purkinje neurons $(P)$ at extremely high levels. One of these neurons (arrowhead) is depicted at higher power using bright-field optics (inset). The inferior olivary nucleus $(\operatorname{InO})$ also is indicated in the autoradiograms and corresponds to dark-field images in the bottom panels. Labeling of this structure also was heterogeneous: $\alpha 1 \mathrm{G}$ was uniformly high; labeling for $\alpha 1 \mathrm{I}$ was limited to the caudal part of the nucleus. Scale bar, $\sim 4.8 \mathrm{~mm}$ (left panels); $250 \mu \mathrm{m}$ (right panels); $50 \mu \mathrm{m}$ (inset); $400 \mu \mathrm{m}$ (bottom panels).

transcript in granule cells of the dentate gyrus and in sensory ganglion neurons. In both of these cell types, T-type channels have been shown to produce sizable spike afterdepolarizing potentials (White et al., 1989; Zhang et al., 1993) that in sensory neurons can trigger bursts of action potentials. It is notable that in sensory neurons of the nodose ganglia, $\mathrm{Ca}_{\mathrm{V}} \mathrm{T}$ gene expression has been directly implicated in the production of T-type calcium current; transfection with an antisense oligonucleotide targeting a sequence shared by the three $\mathrm{Ca}_{\mathrm{V}} \mathrm{T}$ genes specifically and markedly diminished the LVA calcium current in those cells (Lambert et al., 1998).

In sensory neurons of DRG, we saw high expression of $\alpha 1 \mathrm{H}$ and moderate levels of $\alpha 1 \mathrm{I}$ mRNA. Expression of both transcripts was restricted to small- and medium-sized neurons; $\mathrm{Ca}_{\mathrm{V}} \mathrm{T}$ transcripts were not found in the extremely large DRG neurons. These data are in accord with studies of calcium currents of DRG neurons acutely isolated from adult rats, where large T-type currents were present in medium-diameter neurons but were absent in large-diameter neurons (Scroggs and Fox, 1992a). Thus, our results support the view that T-type currents are expressed specifically in smaller sensory neurons that convey thermal and nociceptive information and not in larger neurons that subserve proprioceptive and tactile pathways (Scroggs and Fox, 1992a).

In addition to finding abundant $\mathrm{Ca}_{\mathrm{V}} \mathrm{T}$ mRNA in areas where 
Spinal Cord
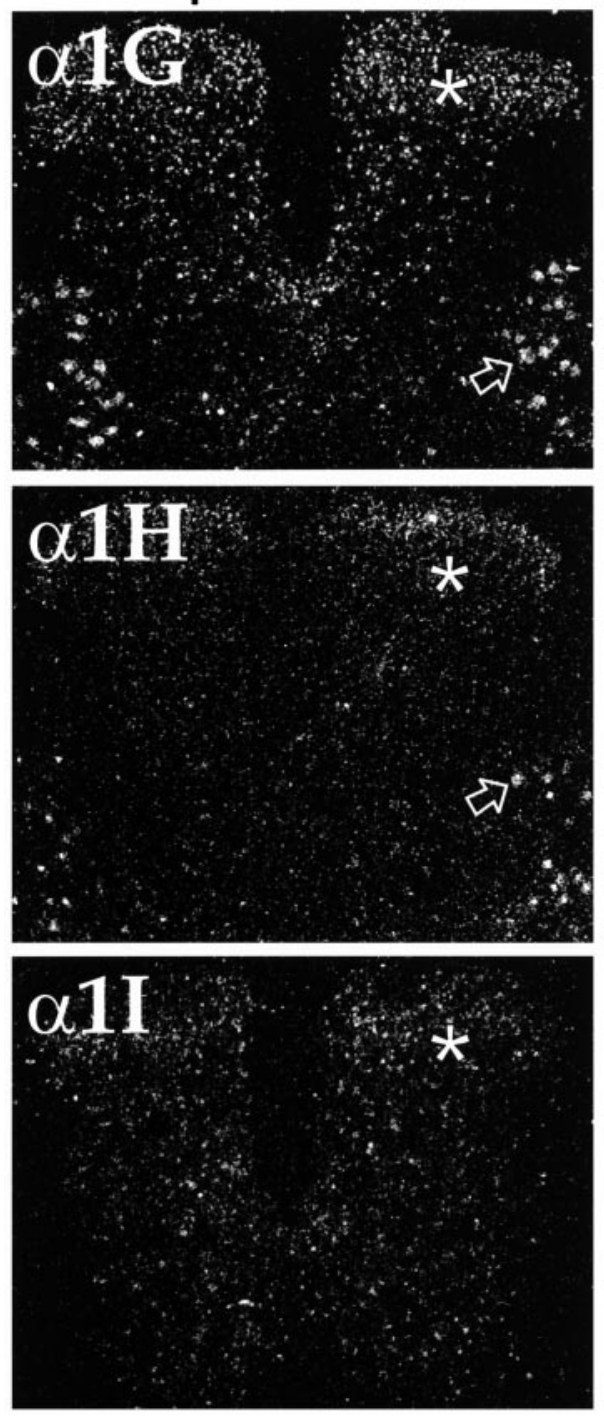

DRG
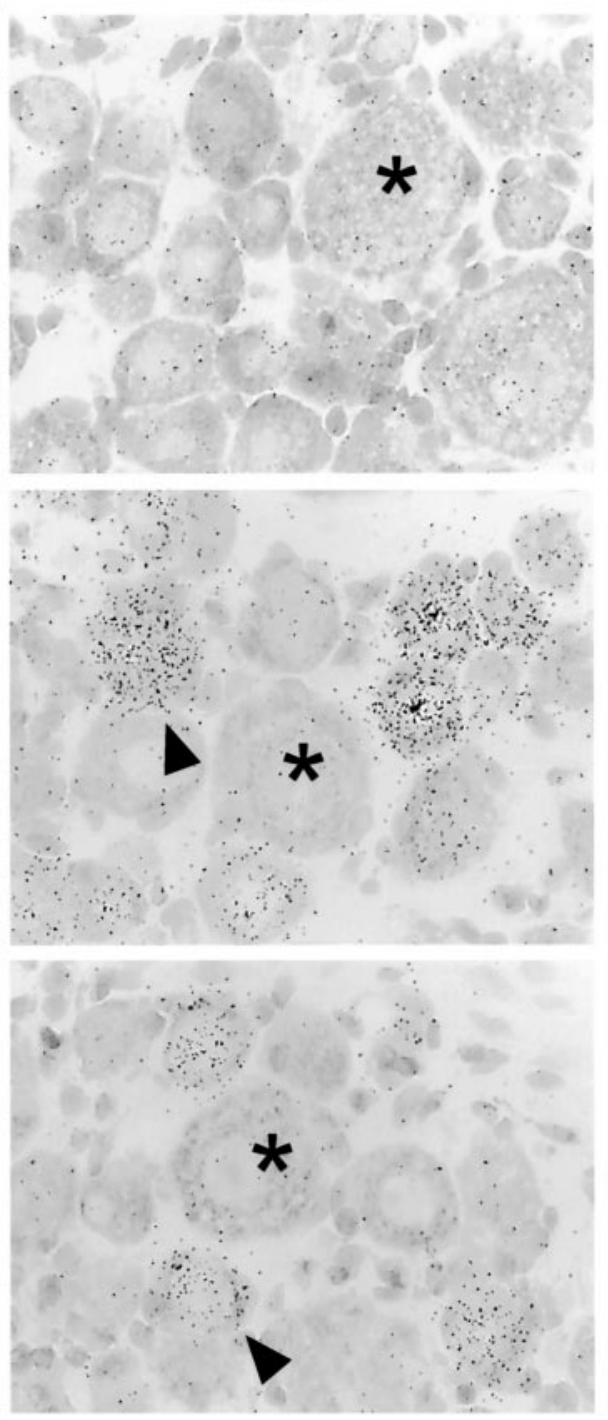

Nodose
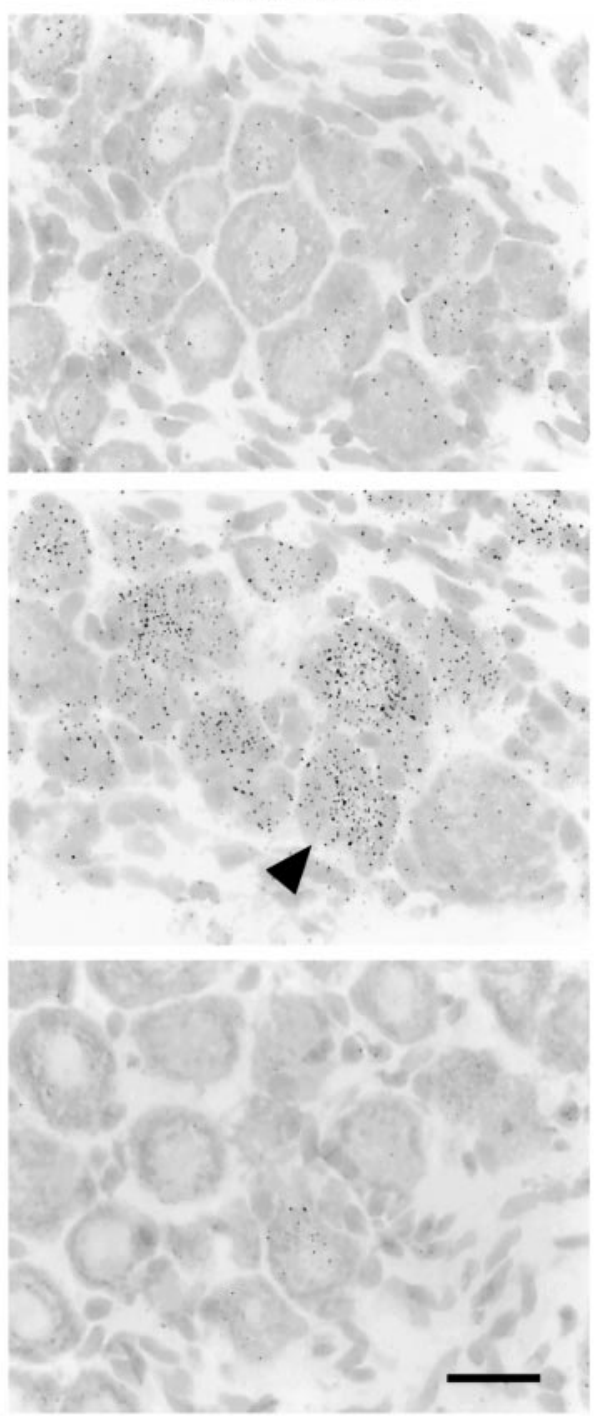

Figure 7. Differential accumulation of $\mathrm{Ca}_{\mathrm{V}} \mathrm{T}$ transcripts in the spinal cord and sensory ganglia. Left panels show low-power dark-field images of transverse sections through the lumbar spinal cord. All three transcripts were present in the dorsal horn (asterisks), with $\alpha 1 \mathrm{H}$ mRNA limited to neurons of the external lamina. Note also that $\alpha 1 \mathrm{G}$ and $\alpha 1 \mathrm{H}$ were expressed in motor neurons in the ventral horn (open arrows). Middle panels show high-power bright-field images of dorsal root ganglia $(D R G)$ neurons. Probes for $\alpha 1 \mathrm{H}$ and $\alpha 1 \mathrm{I}$ labeled small- and medium-sized neurons (arrowheads); in contrast, large neurons (asterisks) were unlabeled. In the nodose ganglia (right panels) expression was for the most part limited to $\alpha 1 \mathrm{H}$ (arrowhead). Scale bar, 400 $\mu \mathrm{m}$ (left panels); $25 \mu \mathrm{m}$ (middle and right panels).

prominent T-type calcium currents have been observed, there were a number of regions where we saw little or no detectable $\mathrm{Ca}_{\mathrm{V}} \mathrm{T}$ expression and where other investigators have failed to find LVA calcium current. For example, we saw no $\mathrm{Ca}_{\mathrm{V}} \mathrm{T}$ expression in the globus pallidus and saw only very low expression of one of the transcripts $(\alpha 1 \mathrm{G})$ in sympathetic ganglia. In neurons of both of these areas, T-type channels were not evident in whole-cell calcium current recordings (Schofield and Ikeda, 1988; Plummer et al., 1989; Surmeier et al., 1994).

\section{Regions of inconsistency between $\mathrm{Ca}_{\mathrm{v}} \mathrm{T}$ expression and recordings of T-type calcium currents}

As noted above, we saw expression of $\mathrm{Ca}_{\mathrm{V}} \mathrm{T}$ transcripts in regions that display prominent T-type currents and failed to detect these transcripts in regions where T-type currents are absent. However, there were also a number of regions reportedly devoid of these currents where $\mathrm{Ca}_{\mathrm{V}} \mathrm{T}$ genes were expressed (e.g., granule cells in the cerebellum and cerebral cortex) and conversely, regions where T-type currents have been recorded but where we found no evidence for $\mathrm{Ca}_{\mathrm{V}} \mathrm{T}$ expression (e.g., olfactory mitral cells).

It is important to point out that comparative characterization of T-type currents in neurons is problematic because a variety of experimental factors can affect these recordings (discussed in Huguenard, 1996). A particular concern for comparing T-type currents is the converging evidence suggesting that a substantial fraction of these channels are localized to relatively distal dendrites (Karst et al., 1993; Markram and Sakmann, 1994; Magee and Johnston, 1995; Kavalali et al., 1997; Mouginot et al., 1997). As a result of this subcellular distribution, recordings from intact neurons are subject to voltage- and space-clamp errors that can have a dramatic impact on the apparent voltage- and time- 
dependent properties of T-type calcium currents generated at distal sites (Destexhe et al., 1996, 1998). However, in dissociated preparations where electrical recordings only sample currents from the soma and proximal dendrites, the complement of calcium channels of a cell may be misrepresented. Therefore, in addition to some of the more obvious caveats to comparison (e.g., species or age differences in the animals being compared), it is important to note that definitive identification and characterization of T-type currents in neurons is difficult and may even be subject to "false negatives."

One region where there were discrepancies between $\mathrm{Ca}_{\mathrm{V}} \mathrm{T}$ expression and T-type current recordings was the cerebellum. For example, Purkinje cells are most often associated with their prominent P-type HVA calcium currents (Mintz et al., 1992), and it has been suggested that T-type currents in these neurons, which are robust in neonatal animals (Regan, 1991), might only be transiently expressed early during postnatal development (Usowicz et al., 1992, but see Kaneda et al., 1990). However the data presented here, which show extremely high levels of $\alpha 1 \mathrm{G}$ mRNA in adult Purkinje cells (Fig. 6), do not support this possibility. Moreover, our preliminary results indicate that expression of $\alpha 1 \mathrm{G}$ mRNA is present in the neonate and actually increases postnatally (E. M. Talley and D. A. Bayliss, unpublished observations).

Similar to Purkinje neurons, cerebellar granule cells also have been studied extensively for the characterization of their HVA current (Slesinger and Lansman, 1991; Pearson et al., 1995; Randall and Tsien, 1995), and T-type currents are reported to be absent in these neurons (Rossi et al., 1994). However, we found a prominent distribution of $\mathrm{Ca}_{\mathrm{V}} \mathrm{T}$ expression in these cells. It is noteworthy that this distribution was heterogeneous. Although moderate levels of $\alpha 1 \mathrm{I}$ were found evenly distributed in granule cells throughout the cerebellar cortex, $\alpha 1 \mathrm{G}$ was found at high levels only in the caudal lobules of both the vermis and the hemispheres (Fig. 6A,B). This type of gradient also has been observed for expression of $\mathrm{K}_{\mathrm{V}} 4.2$ and $\mathrm{K}_{\mathrm{V}} 4.3$ (Serodio and Rudy, 1998), two genes believed to contribute to transient subthreshold potassium currents. Thus, based on the expression of $\mathrm{Ca}_{\mathrm{V}} \mathrm{T}$ - and $\mathrm{K}_{\mathrm{V}}$ 4-family genes, we would expect to find differences in subthreshold membrane properties of rostral and caudal cerebellar granule neurons.

Another area of the CNS where there is curious inconsistency between our findings with regard to $\mathrm{Ca}_{\mathrm{V}} \mathrm{T}$ expression and experiments examining the characteristics of neuronal calcium currents is the cerebral cortex. T-type calcium currents are thought to be more prominent in pyramidal neurons of the neocortex (Giffin et al., 1991; Hamill et al., 1991) when compared with nonpyramidal cells. Furthermore, cells with measurable T-type current were predominantly found in deeper layers, cortical layer $\mathrm{V}$ in the visual cortex (Giffin et al., 1991) or layers V and VI in the medial frontal cortex (de la Pena and Geijo-Barrientos, 1996). In accord with those studies, we found that $\alpha 1 \mathrm{H}$ expression is largely limited to layer $\mathrm{V}$ pyramidal neurons. However, we also found substantial expression of $\alpha 1 \mathrm{G}$ and $\alpha 1 \mathrm{I}$ in all cortical layers, and this expression did not appear to be limited to pyramidal neurons. Given the generalized expression patterns of $\alpha 1 \mathrm{G}$ and $\alpha 1 \mathrm{I}$ in the neocortex, it is not clear why only a restricted population of neurons in this region have been found to display $\mathrm{T}$-type currents.

In addition to observing $\mathrm{Ca}_{\mathrm{V}} \mathrm{T}$ expression in neurons thought to be devoid of T-type currents, there were also cells in which we failed to find $\mathrm{Ca}_{\mathrm{V}} \mathrm{T}$ expression but which appear to have T-type calcium currents. This was the case for olfactory mitral cells, which have been shown to have LVA currents of modest ampli- tude (Wang et al., 1996). However, although they appear to lack expression of known $\mathrm{Ca}_{\mathrm{V}} \mathrm{T}$ gene-family members, these cells are well stained by an antibody to the $\alpha 1 \mathrm{E}$ (HVA family) calcium channel (Yokoyama et al., 1995). It is possible that LVA currents in these neurons receive a contribution from the $\alpha 1 \mathrm{E}$ channel, which can generate currents with some T-type properties (Soong et al., 1993; Meir and Dolphin, 1998) and may account for some of the LVA current in atrial myocytes (Piedras-Renteria et al., 1997). An alternative possibility is that an as yet unidentified gene accounts for the LVA currents in mitral cells. It is worth mentioning at this juncture that in contrast to mitral cells, we found high levels of expression of all three transcripts in granule cells of the olfactory bulb. Calcium currents in these neurons apparently have not been extensively characterized (Bhalla and Bower, 1993).

\section{Heterogeneity of CNS T-type calcium currents}

CNS T-type calcium channels are pharmacologically and physiologically heterogeneous, leading to the hypothesis that at least some of their variability is generated by differences in genes encoding these channels. With respect to pharmacology, T-type currents have shown different sensitivities to block by a number of cations and organic compounds (for review, see Akaike, 1991; Huguenard, 1996). Any discussion of the contribution of the three $\mathrm{Ca}_{\mathrm{V}} \mathrm{T}$ gene products to this differential sensitivity is preliminary because the pharmacological profiles of these clones have not been extensively characterized. It can be pointed out, however, that we do not see any correlation between the expression profiles of any of the three $\mathrm{Ca}_{\mathrm{V}} \mathrm{T}$ transcripts and regions where particular pharmacological attributes have been observed. For example, differential sensitivities to both nickel and amiloride have been noted between DRG neurons and pituitary cells (Todorovic and Lingle, 1998), two regions where we see predominant expression of $\alpha 1 \mathrm{H}$ mRNA. Conversely, thalamic reticular and relay neurons, which express different $\mathrm{Ca}_{\mathrm{V}} \mathrm{T}$ transcripts, have similar sensitivities to both nickel and amiloride (Huguenard and Prince, 1992).

Physiological characterization of the three $\mathrm{Ca}_{\mathrm{V}} \mathrm{T}$ genes has been performed, and there appears to be some correlation between expression of these genes and the properties of T-type currents in different CNS neurons. When expressed in the same cell type (HEK 293 cells), $\alpha 1 \mathrm{G}$ and $\alpha 1 \mathrm{H}$ generate currents with similar kinetic and voltage-dependent properties. In contrast, $\alpha 1 \mathrm{I}$ currents have slower kinetics and depolarized voltage dependence of activation, when compared with the other two channels (Lee et el., 1999).

The contrast in properties between the $\alpha 1 \mathrm{I}$ channels and those of $\alpha 1 \mathrm{G}$ and $\alpha 1 \mathrm{H}$ corresponds to a difference in T-type currents in different cells of the thalamus, a region where these currents have been extensively characterized both in dissociated and intact preparations (Destexhe et al., 1996, 1998). When calcium currents were compared directly in thalamic reticular and thalamic relay neurons (Coulter et al., 1989a; Huguenard and Prince, 1992), it was found that the LVA component was distinctly different in the two cell types. Thalamic reticular neurons, which express high levels of $\alpha 1 \mathrm{I}$ mRNA along with moderate levels of $\alpha 1 \mathrm{H}$, had slower kinetics of activation and inactivation when compared with thalamic relay neurons of the ventral basal complex, a region that appears to exclusively express $\alpha 1 \mathrm{G}$. Moreover, in reticular neurons the voltage range of activation was depolarized relative to that of relay neurons. Given data from the expressed channels, it appears that the slower kinetics and depolarized voltage dependence of activation in reticular neurons may result at least in part 
from their expression of $\alpha 1 \mathrm{I}$. Consistent with this hypothesis, neurons of the lateral habenula, which express both $\alpha 1 \mathrm{G}$ and $\alpha 1 \mathrm{I}$ (Figs. 4H,I, 5), were found to have T-current with physiological properties intermediate between those of reticular and relay neurons (Huguenard et al., 1993).

It should be pointed out that in addition to $\mathrm{Ca}_{\mathrm{V}} \mathrm{T}(\alpha 1 \mathrm{I}$ and $\alpha 1 \mathrm{H})$ expression, thalamic reticular neurons also apparently express somewhat elevated levels of $\alpha 1 \mathrm{E}$ (Soong et al., 1993; Williams et al., 1994; but see Yokoyama et al., 1995). As noted above, this gene is more rapidly inactivating and has a more hyperpolarized threshold for activation than other genes of the HVA family (Soong et al., 1993). Therefore, it may be that a combination of $\alpha 1 \mathrm{E}, \alpha 1 \mathrm{H}$, and $\alpha 1 \mathrm{I}$ contribute to the LVA current in thalamic reticular neurons. In addition, we cannot rule out the possibility that there may be as yet uncloned genes that generate and/or modify LVA currents in these and other CNS neurons.

\section{REFERENCES}

Akaike N (1991) T-type calcium channels in mammalian CNS neurones. Comp Biochem Physiol 98C:31-40.

Bal T, McCormick DA (1993) Mechanisms of oscillatory activity in guinea-pig nucleus reticularis thalami in vitro: a mammalian pacemaker. J Physiol (Lond) 468:669-691.

Bhalla US, Bower JM (1993) Exploring parameter space in detailed single neuron models: simulations of the mitral and granule cells of the olfactory bulb. J Neurophysiol 69:1948-1965.

Catterall WA (1995) Structure and function of voltage-gated ion channels. Annu Rev Biochem 64:493-531.

Coulter DA, Huguenard JR, Prince DA (1989a) Calcium currents in rat thalamocortical relay neurones: kinetic properties of the transient, low-threshold current. J Physiol (Lond) 414:587-604.

Coulter DA, Huguenard JR, Prince DA (1989b) Specific petit mal anticonvulsants reduce calcium currents in thalamic neurons. Neurosci Lett 98:74-78.

Cribbs LL, Lee JH, Yang J, Satin J, Zhang Y, Daud A, Barclay J, Williamson MP, Fox M, Rees M, Perez-Reyes E (1998) Cloning and characterization of $\alpha 1 \mathrm{H}$ from human heart, a member of the T-type calcium channel gene family. Circ Res 83:103-109.

de la Pena E, Geijo-Barrientos E (1996) Laminar localization, morphology, and physiological properties of pyramidal neurons that have the low-threshold calcium current in the guinea-pig medial frontal cortex. J Neurosci 16:5301-5311.

Destexhe A, Contreras D, Steriade M, Sejnowski TJ, Huguenard JR (1996) In vivo, in vitro, and computational analysis of dendritic calcium currents in thalamic reticular neurons. J Neurosci 16:169-185.

Destexhe A, Neubig M, Ulrich D, Huguenard J (1998) Dendritic lowthreshold calcium currents in thalamic relay cells. J Neurosci 18:3574-3588.

Giffin K, Solomon JS, Burkhalter A, Nerbonne JM (1991) Differential expression of voltage-gated calcium channels in identified visual cortical neurons. Neuron 6:321-332.

Gutnick MJ, Yarom Y (1989) Low threshold calcium spikes, intrinsic neuronal oscillation and rhythm generation in the CNS. J Neurosci Methods 28:93-99.

Hamill OP, Huguenard JR, Prince DA (1991) Patch-clamp studies of voltage-gated currents in identified neurons of the rat cerebral cortex. Cereb Cortex 1:48-61.

Herrup K, Kuemerle B (1997) The compartmentalization of the cerebellum. Annu Rev Neurosci 20:61-90.

Huguenard JR (1996) Low-threshold calcium currents in central nervous system neurons. Annu Rev Physiol 58:329-348.

Huguenard JR, Prince DA (1992) A novel T-type current underlies prolonged $\mathrm{Ca}^{2+}$-dependent burst firing in GABAergic neurons of rat thalamic reticular nucleus. J Neurosci 12:3804-3817.

Huguenard JR, Gutnick MJ, Prince DA (1993) Transient $\mathrm{Ca}^{2+}$ currents in neurons isolated from rat lateral habenula. J Neurophysiol 70:158-166.

Hutcheon B, Miura RM, Yarom Y, Puil E (1994) Low-threshold calcium current and resonance in thalamic neurons: a model of frequency preference. J Neurophysiol 71:583-594.

Kaneda M, Wakamori M, Ito C, Akaike N (1990) Low-threshold cal- cium current in isolated Purkinje cell bodies of rat cerebellum. J Neurophysiol 63:1046-1051.

Karst H, Joels M, Wadman WJ (1993) Low-threshold calcium current in dendrites of the adult rat hippocampus. Neurosci Lett 164:154-158.

Kavalali ET, Zhuo M, Bito H, Tsien RW (1997) Dendritic $\mathrm{Ca}^{2+}$ channels characterized by recordings from isolated hippocampal dendritic segments. Neuron 18:651-663.

Lambert RC, McKenna F, Maulet Y, Talley EM, Bayliss DA, Cribbs LL, Lee JH, Perez-Reyes E, Feltz A (1998) Low voltage-activated $\mathrm{Ca}^{2+}$ currents are generated by members of the $\mathrm{Ca}_{\mathrm{V}} \mathrm{T}$ subunit family $(\alpha 1 \mathrm{G} / \mathrm{H})$ in rat primary sensory neurons. J Neurosci 18:8605-8613.

Lee J-H, Daud A, Cribbs LL, Lacerda AE, Pereverzev A, Klockner U, Schneider T, Perez-Reyes E (1999) Cloning and expression of a nove member of the low voltage-activated T-type calcium channel family. J Neurosci 19:1912-1921.

Llinas R, Yarom Y (1981) Electrophysiology of mammalian inferior olivary neurones in vitro. Different types of voltage-dependent ionic conductances. J Physiol (Lond) 315:549-567.

Magee JC, Johnston D (1995) Characterization of single voltage-gated $\mathrm{Na}+$ and $\mathrm{Ca}^{2+}$ channels in apical dendrites of rat CA1 pyramidal neurons. J Physiol (Lond) 487:67-90.

Magee JC, Christofi G, Miyakawa H, Christie B, Lasser-Ross N, Johnston D (1995) Subthreshold synaptic activation of voltage-gated $\mathrm{Ca}^{2+}$ channels mediates a localized $\mathrm{Ca}^{2+}$ influx into the dendrites of hippocampal pyramidal neurons. J Neurophysiol 74:1335-1342.

Magee JC, Avery RB, Christie BR, Johnston D (1996) Dihydropyridinesensitive, voltage-gated $\mathrm{Ca}^{2+}$ channels contribute to the resting intracellular $\mathrm{Ca}^{2+}$ concentration of hippocampal CA1 pyramidal neurons. J Neurophysiol 76:3460-3470.

Manor Y, Rinzel J, Segev I, Yarom Y (1997) Low-amplitude oscillations in the inferior olive: a model based on electrical coupling of neurons with heterogeneous channel densities. J Neurophysiol 77:2736-2752.

Markram H, Sakmann B (1994) Calcium transients in dendrites of neocortical neurons evoked by single subthreshold excitatory postsynaptic potentials via low-voltage-activated calcium channels. Proc Natl Acad Sci USA 91:5207-5211.

McCobb DP, Beam KG (1991) Action potential waveform voltage-clamp commands reveal striking differences in calcium entry via low and high voltage-activated calcium channels. Neuron 7:119-127.

McCormick DA, Bal T (1997) Sleep and arousal: thalamocortical mechanisms. Annu Rev Neurosci 20:185-215.

Meir A, Dolphin AC (1998) Known calcium channel $\alpha 1$ subunits can form low threshold small conductance channels with similarities to native T-type channels. Neuron 20:341-351.

Mintz IM, Venema VJ, Swiderek KM, Lee TD, Bean BP, Adams ME (1992) P-type calcium channels blocked by the spider toxin omegaAga-IVA. Nature 355:827-829.

Miyakawa H, Ross WN, Jaffe D, Callaway JC, Lasser-Ross N, Lisman JE, Johnston D (1992) Synaptically activated increases in $\mathrm{Ca}^{2+}$ concentration in hippocampal CA1 pyramidal cells are primarily due to voltage-gated $\mathrm{Ca}^{2+}$ channels. Neuron 9:1163-1173.

Mouginot D, Bossu JL, Gahwiler BH (1997) Low-threshold $\mathrm{Ca}^{2+}$ currents in dendritic recordings from Purkinje cells in rat cerebellar slice cultures. J Neurosci 17:160-170.

Paxinos G, Watson C (1997) The rat brain in stereotaxic coordinates, Ed 3. San Diego: Academic.

Pearson HA, Sutton KG, Scott RH, Dolphin AC (1995) Characterization of $\mathrm{Ca}^{2+}$ channel currents in cultured rat cerebellar granule neurones. J Physiol (Lond) 482:493-509.

Perez-Reyes E, Schneider T (1995) Molecular biology of calcium channels. Kidney Int 48:1111-1124.

Perez-Reyes E, Cribbs LL, Daud A, Lacerda AE, Barclay J, Williamson MP, Fox M, Rees M, Lee JH (1998a) Molecular characterization of a neuronal low-voltage-activated T-type calcium channel. Nature 391:896-900.

Perez-Reyes E, Cribbs LL, Daud A, Yang J, Lacerda AE, Barclay J, Williamson MP, Fox M, Rees M, Lee J-H (1998b) Molecular characterization of T-type calcium channels. In: Low-voltage-activated T-type calcium channels (Tsien RW, Clozel J-P, Nargeot J, eds), pp 290-306. Chester: Adis International.

Piedras-Renteria ES, Chen CC, Best PM (1997) Antisense oligonucleotides against rat brain $\alpha 1 \mathrm{E}$ DNA and its atrial homologue decrease T-type calcium current in atrial myocytes. Proc Natl Acad Sci USA 94:14936-14941.

Plummer MR, Logothetis DE, Hess P (1989) Elementary properties and 
pharmacological sensitivities of calcium channels in mammalian peripheral neurons. Neuron 2:1453-1463.

Puil E, Meiri H, Yarom Y (1994) Resonant behavior and frequency preferences of thalamic neurons. J Neurophysiol 71:575-582.

Randall A, Tsien RW (1995) Pharmacological dissection of multiple types of $\mathrm{Ca}^{2+}$ channel currents in rat cerebellar granule neurons. J Neurosci 15:2995-3012.

Randall AD, Tsien RW (1997) Contrasting biophysical and pharmacological properties of T-type and R-type calcium channels. Neuropharmacology 36:879-893.

Regan LJ (1991) Voltage-dependent calcium currents in Purkinje cells from rat cerebellar vermis. J Neurosci 11:2259-2269.

Rossi P, D’Angelo E, Magistretti J, Toselli M, Taglietti V (1994) Agedependent expression of high-voltage activated calcium currents during cerebellar granule cell development in situ. Pflügers Arch 429:107-116.

Schofield GG, Ikeda SR (1988) Sodium and calcium currents of acutely isolated adult rat superior cervical ganglion neurons. Pflügers Arch 411:481-490.

Scroggs RS, Fox AP (1992a) Calcium current variation between acutely isolated adult rat dorsal root ganglion neurons of different size. J Physiol (Lond) 445:639-658.

Scroggs RS, Fox AP (1992b) Multiple $\mathrm{Ca}^{2+}$ currents elicited by action potential waveforms in acutely isolated adult rat dorsal root ganglion neurons. J Neurosci 12:1789-1801.

Serodio P, Rudy B (1998) Differential expression of Kv4 K ${ }^{+}$channel subunits mediating subthreshold transient $\mathrm{K}^{+}$(A-type) currents in rat brain. J Neurophysiol 79:1081-1091.

Slesinger PA, Lansman JB (1991) Inactivation of calcium currents in granule cells cultured from mouse cerebellum. J Physiol (Lond) 435:101-121.

Soong TW, Stea A, Hodson CD, Dubel SJ, Vincent SR, Snutch TP (1993) Structure and functional expression of a member of the low voltage-activated calcium channel family. Science 260:1133-1136.

Steriade M, McCormick DA, Sejnowski TJ (1993) Thalamocortical oscillations in the sleeping and aroused brain. Science 262:679-685.

Surmeier DJ, Seno N, Kitai ST (1994) Acutely isolated neurons of the rat globus pallidus exhibit four types of high-voltage-activated $\mathrm{Ca}^{2+}$ current. J Neurophysiol 71:1272-1280.

Talley EM, Sadr NN, Bayliss DA (1997) Postnatal development of sero- tonergic innervation, 5- $\mathrm{HT}_{1 \mathrm{~A}}$ receptor expression, and 5-HT responses in rat motoneurons. J Neurosci 17:4473-4485.

Tarasenko AN, Kostyuk PG, Eremin AV, Isaev DS (1997) Two types of low-voltage-activated $\mathrm{Ca}^{2+}$ channels in neurones of rat laterodorsal thalamic nucleus. J Physiol (Lond) 499:77-86.

Todorovic SM, Lingle CJ (1998) Pharmacological properties of T-type $\mathrm{Ca}^{2+}$ current in adult rat sensory neurons: effects of anticonvulsant and anesthetic agents. J Neurophysiol 79:240-252.

Tsakiridou E, Bertollini L, de Curtis M, Avanzini G, Pape HC (1995) Selective increase in T-type calcium conductance of reticular thalamic neurons in a rat model of absence epilepsy. J Neurosci 15:3110-3117.

Umemiya M, Berger AJ (1994) Properties and function of low- and high-voltage-activated $\mathrm{Ca}^{2+}$ channels in hypoglossal motoneurons. J Neurosci 14:5652-5660.

Usowicz MM, Sugimori M, Cherksey B, Llinas R (1992) P-type calcium channels in the somata and dendrites of adult cerebellar Purkinje cells. Neuron 9:1185-1199.

Wang X, McKenzie JS, Kemm RE (1996) Whole cell calcium currents in acutely isolated olfactory bulb output neurons of the rat. J Neurophysiol 75:1138-1151.

Welsh JP, Lang EJ, Suglhara I, Llinas R (1995) Dynamic organization of motor control within the olivocerebellar system. Nature 374:453-457.

White G, Lovinger DM, Weight FF (1989) Transient low-threshold $\mathrm{Ca}^{2+}$ current triggers burst firing through an afterdepolarizing potential in an adult mammalian neuron. Proc Natl Acad Sci USA 86:6802-6806.

Williams ME, Marubio LM, Deal CR, Hans M, Brust PF, Philipson LH, Miller RJ, Johnson EC, Harpold MM, Ellis SB (1994) Structure and functional characterization of neuronal alpha $1 \mathrm{E}$ calcium channel subtypes. J Biol Chem 269:22347-22357.

Yokoyama CT, Westenbroek RE, Hell JW, Soong TW, Snutch TP, Catterall WA (1995) Biochemical properties and subcellular distribution of the neuronal class E calcium channel alpha 1 subunit. J Neurosci 15:6419-6432.

Zhang L, Valiante TA, Carlen PL (1993) Contribution of the lowthreshold $\mathrm{T}$-type calcium current in generating the post-spike depolarizing afterpotential in dentate granule neurons of immature rats. J Neurophysiol 70:223-231. 